This PDF is a selection from an out-of-print volume from the National Bureau of Economic Research

Volume Title: An Appraisal of the 1950 Census Income Data Volume Author/Editor: Conference on Research in Income and Wealth Volume Publisher: Princeton University Press

Volume ISBN: 0-691-04102-4

Volume URL: http://www.nber.org/books/unkn58-2

Publication Date: 1958

Chapter Title: The Relation of Census Income Distribution Statistics to Other Income Data

Chapter Author: Selma F. Goldsmith

Chapter URL: http://www.nber.org/chapters/c1050

Chapter pages in book: (p. 63 - 122) 


\title{
The Relation of Census Income Distribution Statistics to Other Income Data
}

\author{
Selma F. Goldsimith, office of BuSiness eCONOMics, \\ DEPARTMENT OF COMMERCE
}

In 1912 when Frank Streightoff, after an exhaustive analysis of the available data, abandoned his attempt to estimate a distribution of incomes by size for the United States, he argued that the basic material necessary for a satisfactory study was simply not to be found. ${ }^{1}$ I wonder how he would react to the multiplicity of global distributions that would be available to him today?

For example, if he wished to group families and unattached individuals into broad income classes in terms of their 1954 incomes, he might place in the "under $\$ 2,000$ " category $141 / 2$ million consumer units if he used Census Bureau figures, 10 million if he used the appropriate Survey of Consumer Finances data for families and unattached individuals (rather than those for spending units), or 8 million if he used the figures of the Office of Business Economics. Streightoff was a careful worker so that he would discover quickly that the 10 million figure was relatively low because it excluded the quasi-household population (persons living in lodging houses, hotels, and so forth) but he would raise it by less than 1 million for that reason. He would note, also, that the 8 million figure was lower than the other two partly because it was based on a broader income concept covering certain nonmoney as well as money items of income, while the $14 \frac{1}{2}$ million and 11 million totals referred to money incomes, defined, however, in just about the same way in both instances.

But he would be somewhat surprised, when he related these figures to the total of 51 million families and unattached individuals in the nation, to find that the proportion of consumer units with incomes under $\$ 2,000$ could be any one of the following: almost 3 in 10 (Census Bureau), somewhat over 2 in 10 (Survey of Consumer Finances) or, allowing for nonmoney incomes, 1.7 in 10 (Office of Business Economics).

Note: The views in this paper are those of the author and not of the Office of Business Economics.

${ }^{1}$ Frank H. Streightoff, "The Distribution of Incomes in the United States," Studies in History, Economics and Public Law, Columbia University Press, 1912. 
To which figures would Streightoff turn if he were interested not so much in the over-all distribution of income but in component income distributions that might help to explain some of the changes in income size distribution that take place over time? For three reasons he would probably decide that his primary source material would be the income data provided by the Census Bureau:

1. The Census Bureau income data are collected and presented for persons as well as for families; the other data sources are available only for "consumer" or "spending" units. The individual rather than the family becomes the significant unit of measurement when attention is focused on the variables determining the distribution of income by size, although how individual income recipients combine into family units is, of course, also of importance. ${ }^{2}$

2. The decennial censuses provide income size-distribution data for persons classified by detailed occupation and industry groupings, by residence, and by age, education, and numerous other variables. For the most part such detailed cross-classifications are not available from other sources. ${ }^{3}$

3. The Census Bureau data are our main source of information on longer-run changes in income distribution. The 1940 and 1950 decennial censuses provide cross-classifications of income data for 1939 and 1949 (although limited in the former case to wages and salaries), and with the 1960 census we hope to have similar and perhaps improved income data for 1959. No other set of income distribution statistics provides detailed cross-classifications of income data for all the population and for the same long span of years.

The Census Bureau data on income size distribution that are presently available are described in detail in other papers in this volume (see particularly Edwin D. Goldfield's paper). Briefly, they include nationwide frequency distributions by total money income level, both for families and unattached individuals, and for persons, for the year 1949 from the 1950 Census of Population, and for each year from 1944 to 1954 from the Current Population Surveys (CPS) of the Census Bureau. In addition, some distributions are available by size of specific types of income, the most important being the frequency distributions for 1939 and 1949 of persons by size of wage and salary income, cross-classified either by detailed occupation or industry, from the two decennial censuses. Both the annual

${ }^{2}$ See Simon Kuznets, "The Why and How of Distributions of Income by Size," in Volume Five (1943) of Studies in Income and Wealth (see the list of publications of the Conference at the back of this volume).

${ }^{8}$ Note should be taken also of the Old-Age and Survivors Insurance (OASI) wage and salary data, which will become increasingly useful in this connection because of the broader coverage of workers introduced in 1951 and 1955. 


\section{CENSUS INCOME DISTRIBUTIONS}

and decennial census distributions for families and for persons are presented with a variety of other cross-classifications. Separate distributions for states are available from the 1940 and 1950 decennial censuses, and distributions for individual counties and cities from the 1950 census.

\section{List of Comparisons with Other Income Data}

Possible comparisons between the Census Bureau income distribution data and other income series prepared in the federal government can be grouped into two main categories: comparisons with other estimates of income size distribution, including data for the United States as a whole, for large component population groups, or for smaller groups for which income data are available, and comparisons of the income totals accounted for by the inflated census surveys with income totals estimated by other governmental agencies.

\section{INCOME DISTRIBUTION COMPARISONS}

The major sets of data on income size distribution that may be compared with the Census Bureau statistics are the following:

1. Distributions by money income level from the Surveys of Consumer Finances (SCF), which are conducted by the Board of Governors of the Federal Reserve System in cooperation with the Survey Research Center of the University of Michigan and are available annually for 1945 through 1955. Although most tabulations of the data from these surveys are by spending units, special income size distributions for families and unattached individuals comparable in definition with the census data are also available for each year.

2. Distributions of families and unattached individuals by family personal income level prepared in the Office of Business Economics (OBE). In these distributions the consumer unit is defined in the same way as in the CPS series, but the definition of income is broader, covering various nonmoney items in addition to the money income concept used in the CPS and in the SCF. The OBE income distribution series is integrated statistically as well as definitionally with its aggregate personal income series; its money income component is a substantially larger total than the one accounted for in the CPS. OBE distributions are available for 1944, 1946, 1947, and 1950 to 1955; in addition, unofficial estimates with comparable definitions have been prepared for several prewar years.

3. Distributions of workers covered under the Old-Age and Survi- 
vors Insurance (OASI) program by size classes of their "covered" wages and salaries or self-employment income. These distributions, which refer to persons rather than families, and to wages and salaries (and to self-employment income for recent years) rather than total income, are available annually since 1937 . With the expansion in the coverage of the program in 1951 and again in 1955, difficulties in making comparisons with the OASI data will be much reduced because the noncovered sector has become relatively small. The top limit of $\$ 4,200$ - the total amount of wages subject to tax in any one year-will still be a limiting factor in making comparisons with other wage and salary distributions, such as those of the Census Bureau.

4. Annual distributions of federal individual income tax returns by level of adjusted gross income. The unit of tabulation, the tax return, is not equivalent either to families or persons but is a mixture of both, and the income definition is narrower in some ways and broader in others than that used in the CPS. Nevertheless, with appropriate modification these annual distributions can be compared with the survey data and are particularly important for the period beginning with World War II when the introduction of low filing requirements greatly increased the coverage of the tax-return data.

5. Distributions of urban families and single consumers in 1950 by money income level from the Bureau of Labor Statistics Survey of Consumer Expenditures in 1950. In making comparisons with this set of urban data, allowance must be made for differences in the definition of the consumer unit, particularly with respect to the time period to which the definition refers, as is discussed in a later section.

6. Distributions of selected professional groups by level of professional net earnings (self-employment earnings and professional salaries) from OBE mail-questionnaire surveys. The most recent of the large-scale surveys cover physicians (1949), dentists (1948), and lawyers (1947 and 1954).

\section{TOTAL INCOME COMPARISONS}

Comparisons under the second heading-between amounts of income accounted for in inflated census surveys and aggregate income data from other sources-are listed below. Although the Census Bureau does not publish aggregate amounts of income accounted for in their various surveys, such estimates can be derived by multiplying the frequencies in each income bracket by an estimated mean income for that bracket, including one for the top "and over" bracket where dollar amounts of income were not re- 
quested by the Census Bureau enumerators. Each of the comparisons listed below requires numerous special adjustments in the basic series to allow for differences in income definition and coverage between the Census Bureau statistics and those from the specified source.

7. Comparisons of the CPS income totals with the annual овE personal income series for the United States as a whole, separately for different types of income, for example, wages and salaries, selfemployment income, and so forth.

8. Comparisons of the CPS income totals for various types of income with the totals reported on federal individual income tax returns.

9. Comparisons of the decennial census income data for states and regions with the $O B E$ state personal income series.

10. Comparisons of the decennial census data on wages and salaries for separate industry classifications with the OBE series on wages and salaries by industry.

11. Comparisons of the CPS income data for farm families with the series on total net income from farming and from other sources received by farm operators and by all persons on farms, prepared by the Agricultural Marketing Service, Department of Agriculture.

All of these comparisons cannot be covered adequately in a single paper. Moreover, a number of them are the subject matter of other reports in this volume. The present paper will therefore turn first to the items not covered in other papers; to comparisons with the aggregate income figures in the овE personal income series and with the aggregate amounts reported on federal individual income tax returns-items 7 and 8 above. This is followed by a general discussion of differences among the several sets of family income size distributions, that is, comparisons 1 and $2 .^{4}$

The two comparisons listed above that are not covered in this or other papers in this volume-items 6 and 9-both refer to series prepared in the Office of Business Economics; to OBE income data for selected professional groups and to the $O B E$ state personal income series. Their omission here does not mean that these comparisons are believed to be unimportant but indicates merely that they called for more time or more specialized knowledge than could be furnished by this author. Comparison between the 1950 decennial census income distribution data for states and the овE state income series, appropriately adjusted to allow for definitional

"In connection with this discussion, the reader is referred to the FrechtlingMaynes-Sirken paper in this volume for a more detailed analysis of differences between the CPS and the SCF income distributions. 
differences, would be exceedingly interesting as a guide in appraising the Census Bureau income data for smaller geographic areas, for example, for individual counties, for which the 1950 decennial census provides the only official income statistics that are available.

\section{Comparison of Income Totals from Field Surveys, Federal Individual Income Tax Returns, and $O B E$ Personal Income Series}

Comparisons of income totals derived from the oBE personal income series with corresponding amounts accounted for in a number of "blown-up" sample field surveys, and with amounts reported on federal individual income tax returns, were summarized in a paper presented at our 1949 Income Conference. ${ }^{5}$ The tables shown here bring those earlier comparisons, which extended through 1948, up to date. Parts of the following discussion are necessarily somewhat repetitive of the earlier paper.

\section{TOTAL MONEY INCOME COVERED IN FIELD SURVEYS}

In Table 1 aggregate family money incomes accounted for in 23 "blown-up" sample field surveys of family income are compared with corresponding estimates derived from the oBE personal income series. Included are the 1941 Survey of Spending and Saving in Wartime (sssw) conducted jointly by the Bureau of Labor Statistics and the Bureau of Human Nutrition and Home Economics, 11 annual Current Population Surveys of the Census Bureau covering the years 1944 through 1954 (including a farm family survey for 1946 made by the then Bureau of Agricultural Economics), the 1950 Census of Population, and 10 Surveys of Consumer Finances, conducted by the Board of Governors of the Federal Reserve System in cooperation with the Survey Research Center of the University of Michigan, covering 1945 through 1954.

The OBE family money income totals in Table 1 , with which the income aggregates from the field surveys are compared, were derived by making two sets of adjustments in the OBE personal income series. The first of these was to subtract income flows included in personal income which are not received by families and unattached individuals. This subtraction yielded the family personal income totals shown in column 2, which are the totals accounted for in the OBE income size-distribution series.

The items subtracted from personal income to derive column 2

' ${ }^{5}$ Selma F. Goldsmith, "Appraisal of Basic Data Available for Constructing Income Size Distributions," in Volume Thirteen (1951) of Studies in Income and Wealth, pp. 266-372. 
TABLE 1

Total Family Money Income as Estimated from oBe Personal. Income Series and Covered in Field Surveys, 1941 and 1944-1954

(billions of dollars, except cols. 7-9)

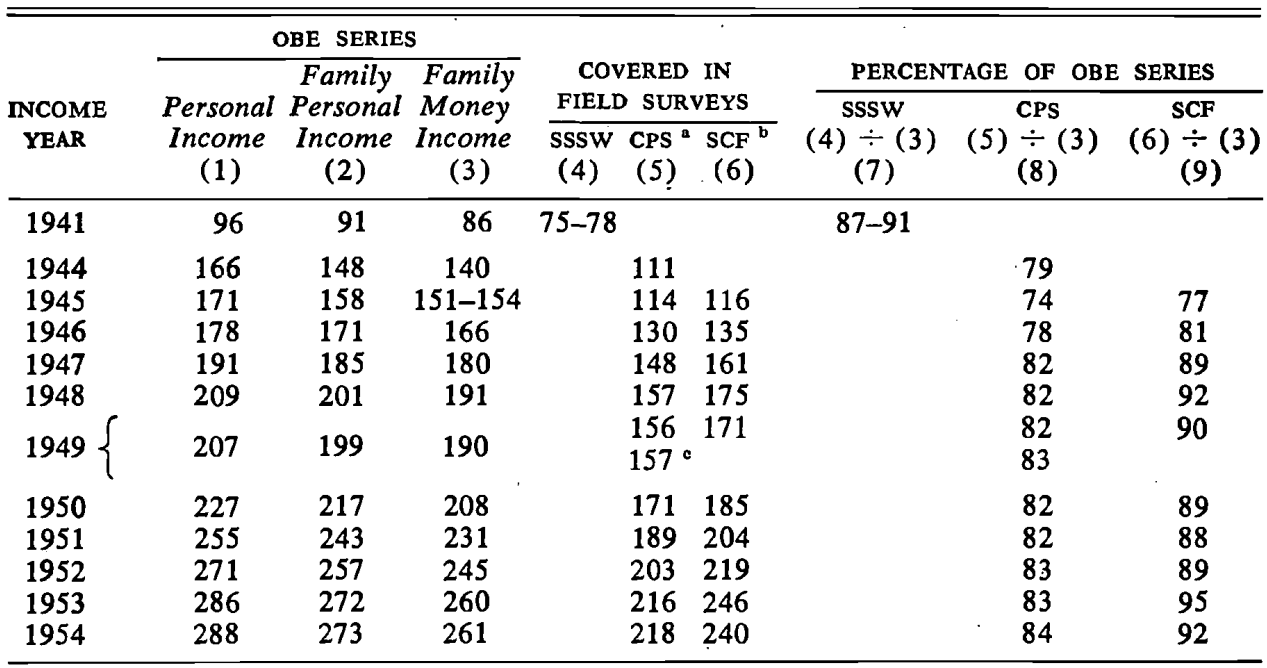

amount accounted for in income distributions of families and unattached individuals from Current Population Surveys, except as noted.

${ }^{b}$ Excluding quasi-household population.

- Amount accounted for in 1949 income distribution of families and unattached individuals from 1950 decennial census.

Note: For detailed technical notes on all the tables in this paper, see the Appendix.
The following abbreviations have been used in this and subsequent tables: OBE (Office of Business Economics, Dept. of Commerce); sssw (1941 Survey of Spending and Saving in Wartime, Bureaus of Labor Statistics and of Human Nutrition and Home Economics); CPS (Current Population Survey, Bureau of the Census); and SCF (Survey of Consumer Finances, Board of Governors of the Federal Reserve System).

included the following estimates: income retained by private pension, trust, and welfare funds, incomes of persons who died or entered the armed forces during the year, and incomes of nonprofit institutions and of institutional residents, including members of the armed forces living on post. In recent years the total amount subtracted to derive family personal income accounted for about 5 per cent of personal income.

The second set of adjustments was to subtract nonmoney items of income not covered in the field surveys and to allow for various other differences in income definition between the family personal income and family money income concepts. The most important items under this heading were the subtraction of the gross value of food and fuel produced and consumed on farms, the gross rental value of farm homes, the net rental value of nonfarm owner-occupied homes, wages in kind, imputed interest (representing the value 
of free services to individuals by banks and the property income of life insurance companies), the value of farm inventory change, and the noncorporate nonfarm inventory valuation adjustment; and the addition of personal contributions for social insurance, estimated net income from roomers and boarders in private homes, and periodic payments received by consumer units from life insurance companies.

Column 3 of Table 1 shows the resulting estimates of aggregate family money income derived from the personal income series. The totals run about 9 to 10 per cent lower than the personal income series in recent years.

As Table 1 indicates, the amounts covered in the various field surveys are lower than the family money income totals in the OBE series. The 1941 sssw survey accounted for about 90 per cent of the comparable OBE money income total, and the SCF since 1947 usually accounted for about that proportion. The CPS since 1947 covered some 82 to 84 per cent of the corresponding OBE family money income totals.

In order to avoid misunderstanding, some of the qualifications that attach to comparisons of this type which were discussed at our 1949 Conference, aside from those relating to sampling variability, must be repeated here. These apply not only to Table 1 but to the following tables as well.

In the first place, some understatement of income is to be expected in all field interview studies if only because some respondents are apt to forget minor or irregular amounts of income and because others may purposely understate their incomes for varied reasons. Furthermore, as the Census Bureau states in each of its income reports, not only are the schedule entries for income of the family members in most cases based on memory rather than on records, but "in the majority of instances on the memory or knowledge of some one person, usually the wife of the family head." It would be indeed surprising if the wife could report fully on all items of income for the entire family unit.

The purpose of comparisons between field survey and OBE income aggregates is not merely to point out that understatement exists in the surveys, but to study variations in the extent of undercoverage among different surveys and different types of income. Such comparisons may indicate why various survey income size distributions differ from each other and may suggest areas in which improvements in survey techniques are needed. As the other papers in this volume make abundantly clear, comparisons of income totals represent only one of several methods of appraising the accuracy of survey data. 


\section{CENSUS INCOME DISTRIBUTIONS}

Second, the comparisons of aggregate income presented in these tables should not be regarded as precise measures of income understatement in the field surveys. In making the adjustments in the personal income series listed above, full allowance could not be made for all the differences in income definition and coverage between the surveys and the OBE series, and a few of the adjustments are necessarily rough approximations of the particular income item (for example, roomer-boarder income). These factors introduce some error in the comparisons for total income in Table 1, and for the separate types of income in Table 2, below.

The income totals accounted for in the "inflated" cPs are also approximate. That is, they were derived by multiplying the number of consumer units in each income bracket by an estimated mean for the bracket, and then summing the results over all income brackets. By varying the estimated means, somewhat different results might have been obtained, but some experimentation indicated that various alternative figures would change the percentage coverage of the CPS in Table 1 by only 1 or at most 2 percentage points.

Finally, there is the question of the extent of possible error in the personal income series itself. In this connection the absolute amount of the difference between the OBE and the survey aggregates is of importance. In each year from 1951 through 1954 the "inflated" CPS accounted for \$40-odd billion less family money income than the comparable oBE series. The deficiency in the SCF in this period, except for 1953 , was $\$ 20$ to 25 billion. No serious student of the national income statistics would suggest that the aggregate money income embodied in the OBE personal income series could be overstated by anything like these orders of magnitude. The question, rather, is whether very much smaller errors may attach to the several components of the personal income series, which together may serve to explain some of the excess of the OBE-based series over the totals accounted for in the surveys.

To answer this question fully would require repeating much of the detailed discussion of the reliability of the national income and product estimates set forth by the OBE in the National Income Supplement, $1954 .^{6}$ The discussion indicates that while the estimates for the components of personal income have various shortcomings, the personal income total itself is believed to be "subject to only a small percentage of error" (page 66). It is most improbable that errors in the personal income series would be large enough to affect to any substantial extent the differences shown in Table 1 for total

\footnotetext{
${ }^{\circ}$ National Income Supplement, 1954; see pages 62-67, and the detailed descriptions of methodology for each of the major income shares in the various sections of Part $\mathrm{nI}$ of the Supplement.
} 
income, nor would they alter significantly the broad relationships between survey and OBE income totals for the separate types of income in Table 2.

As is indicated in the National Income Supplement, estimates of the largest component of personal income, wages and salaries, rank highest in reliability among the income shares mainly because of the adequacy of the social security data on which they are based. The extent of error is relatively small, also, for the important items of government transfer payments and dividends.

Certain of the personal income components are subject to greater error, for example, rent and interest income of persons. The estimates for these income shares are residuals, based on the subtraction of business receipts from total payments in each category, and the source data on rent in particular are far from satisfactory. However, monetary rent and interest account for only a small fraction of total family money income, and inaccuracies in their measurement can have little effect on the over-all estimates in Table 1. In 1954, for example, monetary interest and rent of persons amounted to $\$ 13$ billion, or only 5 per cent of total family money income. The disparity between this figure and the corresponding amount probably accounted for in the 1954 CPS is so large that the broad pattern of income differences developed in Table 2 would not be significantly affected by any reasonable estimates of the possible error in the OBE series for these shares.

The entrepreneurial income component of personal income is also subject to shortcomings, as is indicated in the National Income Supplement. However, for recent years the broadened coverage of the federal income tax, the extensive tabulations of business income made available by the Internal Revenue Service (IRS), and the audit studies of that agency have combined to improve markedly the source material available for constructing the annual entrepreneurial income series.

Net income from nonfarm business is now estimated largely on the basis of data reported on federal individual income tax returns adjusted upward to allow for nonreporting firms and for income understatement as determined from the IRs 1949 audit study. ${ }^{7}$ Professional incomes are based on numbers of practitioners as shown in the censuses of population and records of the professional associations, together with average net income data derived mainly from $\mathrm{OBE}$ questionnaire surveys. For the farm sector, the net income series is taken directly from the Department of Agriculture, which

\footnotetext{
${ }^{7}$ For a detailed description of the methods used to develop the noncorporate business income series (separately for about sixty-five industry subgroups) see National Income Supplement, 1954, Part in, sec. 3
} 
estimates gross income and production expenses in great detail.

In summary, the figures in Table 1 are open to some error, and differences of a few percentage points in the income coverage of the various surveys should not be regarded as significant. However, the statistics are believed to be entirely adequate for summarizing major differences in income coverage among surveys and (in Tables 2 and 3 ) among different types of income.

Two points emerge from the comparisons in Table 1. The first is the lower coverage of income in the CPS than in the SCF. This reflects in large part the heavier concentration of consumer units in income brackets below $\$ 1,000$ and the smaller proportions in the upper income range found in the CPS than in the SCF samples.

The second point is the marked year-to-year stability in relative income coverage shown by the CPS. After ranging between 75 and 80 per cent in the years immediately following World War II, the CPS income coverage increased to 82 per cent in 1947 and has varied only between 82 and 84 per cent ever since. In contrast, the relative amount of income accounted for in the SCF increased sharply in 1953-rising from a level of about 90 per cent of the comparable OBE series to 95 per cent. A marked increase in relative income coverage also occurred in 1947. Such variations in the proportion of income accounted for, which may perhaps reflect commendable improvements in survey techniques, must be kept in mind as a limiting factor in using the survey figures to measure year-to-year changes in income size distribution.

In connection with the 95 per cent coverage figure for 1953 , it should be noted that the actual income coverage of the SCF is about 1 to 2 percentage points higher than the figures in Table 1. This is because the quasi-household population (persons living in lodging houses, hotels, and so forth) is not covered in these surveys whereas the income of this population group is included in the OBE series. In view of the very high coverage of SCF income in 1953 it would seem to be a good idea for those concerned both with the SCF and CPS to use that year as a starting point for analyzing the separate amounts of income of various types accounted for in their surveys, and to appraise the reliability and year-to-year comparability of their survey income distribution data in part at least in those terms.

SEPARATE TYPES OF INCOME REPORTED IN CENSUS BUREAU SURVEYS

Amounts of each of several major types of income covered in the Census Bureau nonfarm plus Bureau of Agricultural Economics farm survey for 1946 and in the CPS for 1954 are compared with the 


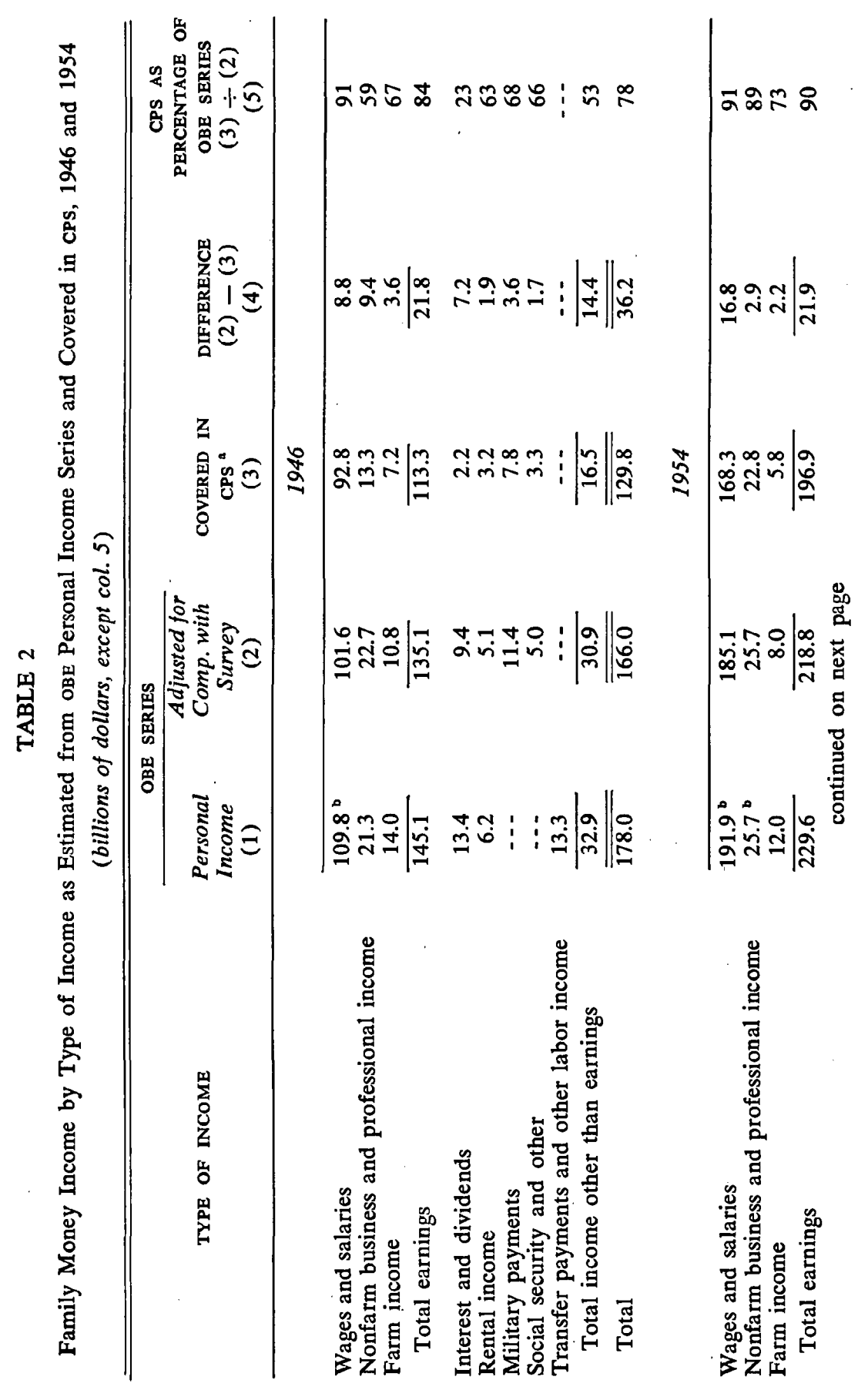




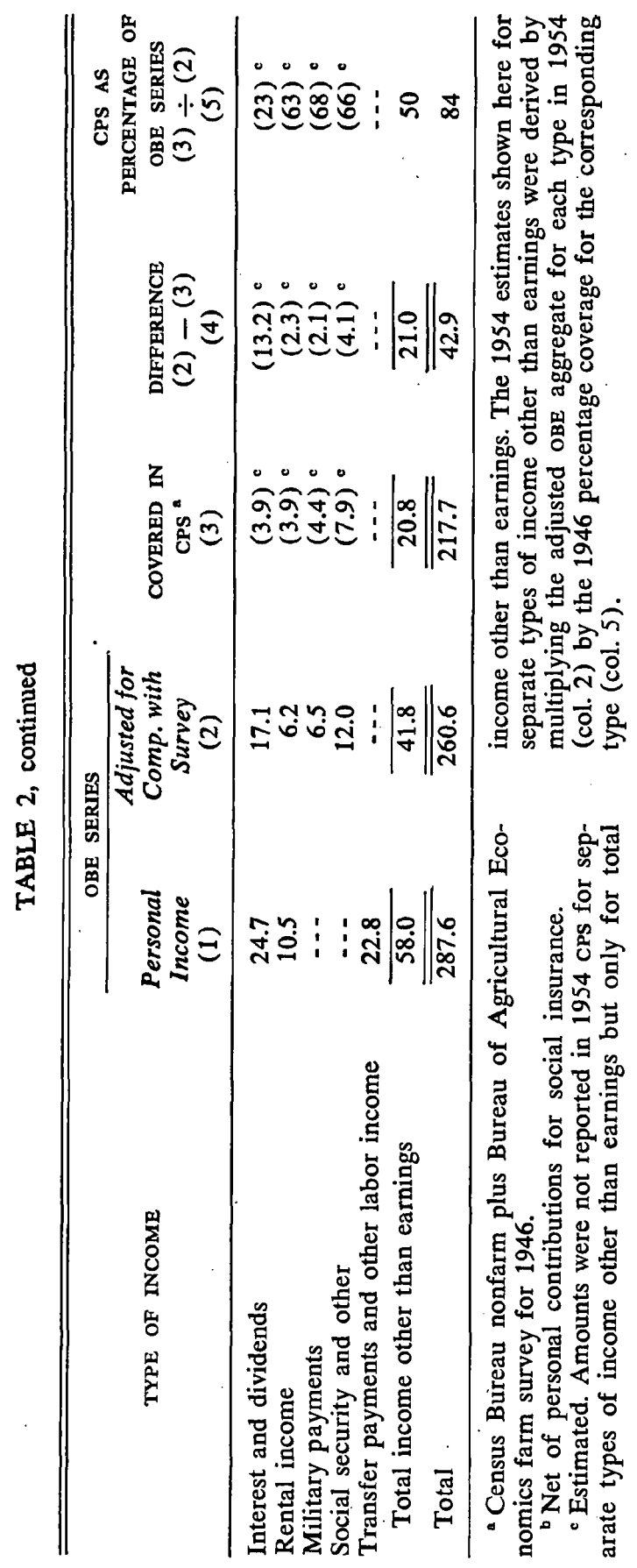


OBE series in Table 2. The 1946 and 1954 surveys both accounted for 91 per cent of wages or salaries. For the nonfarm entrepreneurial income sector, the 89 per cent coverage in 1954 was markedly higher than the 59 per cent in 1946, whereas for net farm income the coverage was fairly similar, 73 and 67 per cent.

In contrast to these earnings items, only about one-half of total money income other than earnings was accounted for in the 1954 CPS, not greatly different but somewhat less than in 1946. The 1954 CPs schedule did not call for separate reporting of the various types of income other than earnings but only for their total. However to determine the distribution of missing income in the 1954 survey by type of income, rough estimates are included in Table 2 for the survey coverage of each of four major types of income other than earnings. These were based on the assumption that the 1954 percentage coverage for each of these four income types. was the same as in 1946, the latest year for which separate survey data are available, that is, that the 1954 survey covered about two-thirds of rent, military payments, and social insurance benefits, and about onefourth of interest and dividends. The assumption is not unreasonable since estimates of 1954 survey income coverage for the four separate items of income other than earnings, derived in this manner, are found when added together to be approximately equal to the amount of total income other than earnings actually reported in the 1954 survey (column 3 of Table 2 ).

To summarize, of the $\$ 43$ billion of income not covered in the 1954 CPS, about $\$ 17$ billion was wages and salaries, $\$ 5$ billion business and professional income, $\$ 15$ billion interest, dividends, and rent, and about $\$ 6$ billion social insurance and veterans' payments, and miscellaneous income. Since income understatement in the survey appears in all of the various types of income, it probably prevails in all ranges of the income scale though not, of course, in equal proportions in the various income brackets.

\section{INCOMES REPORTED ON INDIVIDUAL INCOME TAX RETURNS}

Comparisons between amounts of income covered on federal individual income tax returns and the OBE series are shown for 1946, 1951, and 1952 in Table 3. Because of the nature of the available data it is simpler to compare the tax-return data with the oBE figures rather than directly with the Census Bureau surveys. Adjustments made in the OBE and tax-return series to achieve as much comparability as possible are described in the technical notes to Table 3 , in the Appendix.

Of the major income shares shown in the table, the coverage of tax returns is highest-about 95 per cent-for wages and salaries. 


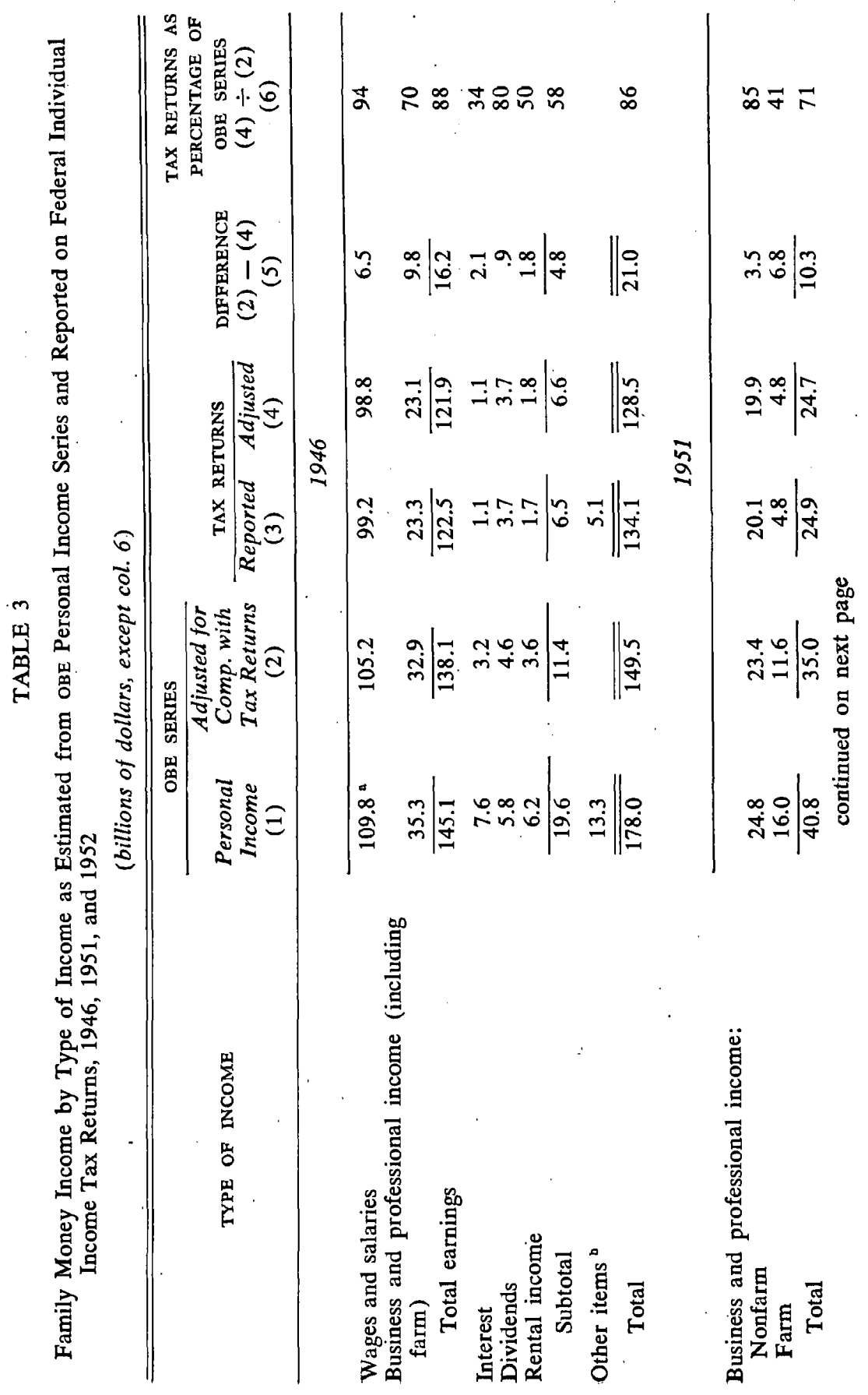




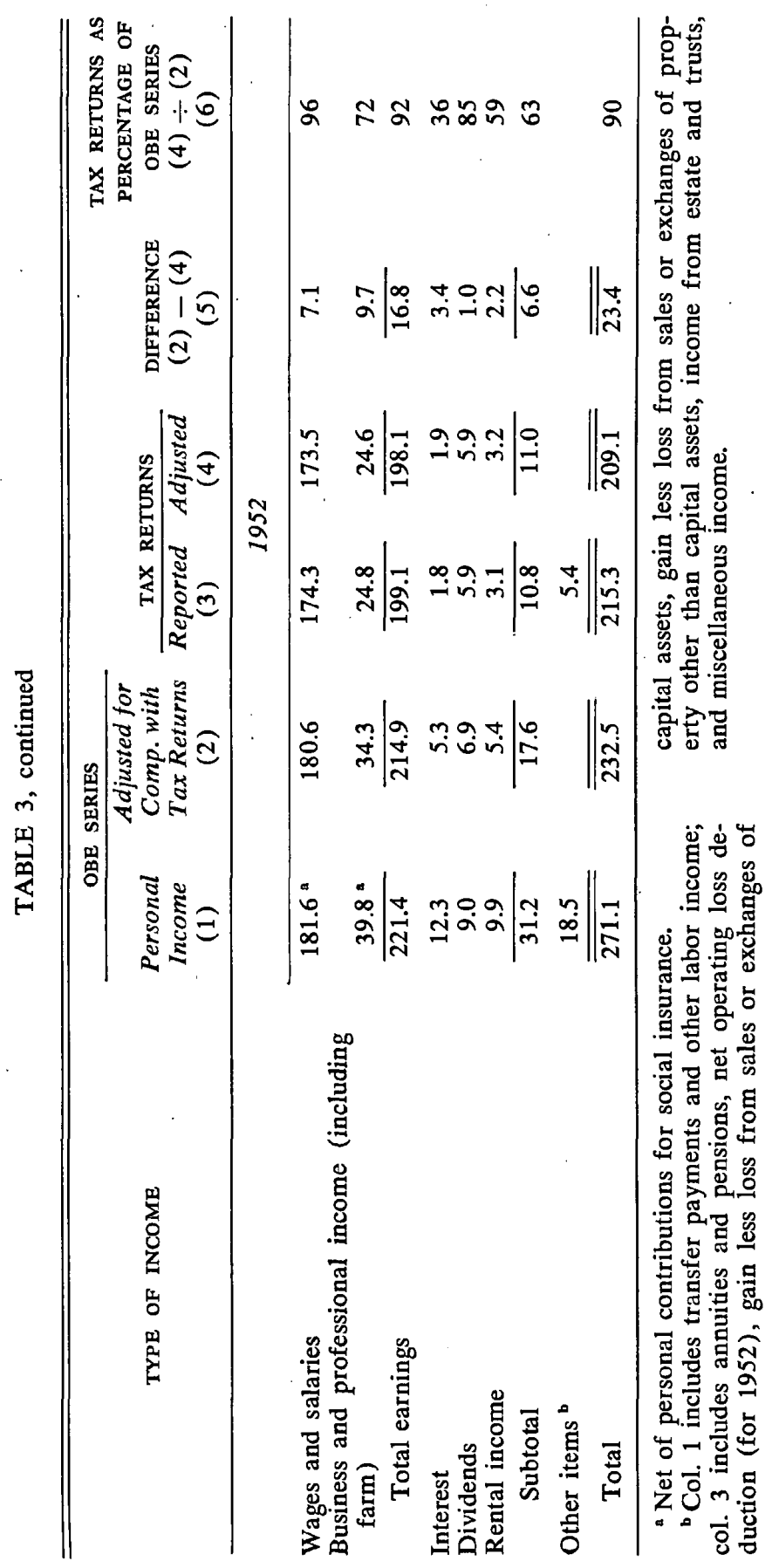




\section{CENSUS INCOME DISTRIBUTIONS}

This is not surprising in view of the withholding system introduced during World War II and the fact that employer reports on wages and salaries paid serve as a basis both for the reports of individuals on their income tax returns and for a substantial sector of wages and salaries in the personal income series. About 70 per cent of business and professional income is accounted for on tax returns, with relative coverage much higher in the nonfarm than in the farm sector. For the nonfarm, the coverage is about 85 per cent (see the earlier discussion of the relation between the tax return and the $\mathrm{OBE}$ series for the nonfarm business sector), whereas for the farm; as nearly as can be measured, it is only around 40 per cent. Monetary interest on tax returns represented about 35 per cent of the comparable OBE figure, and, in 1952, dividends about 85 per cent, and rental income 60 per cent. ${ }^{8}$

These percentages are not to be regarded as precise because the available data did not permit full allowance for all of the definitional differences between the personal income components and the corresponding income concepts in tax returns. ${ }^{9}$ This factor is probably relatively most important in the case of farm income for which information is not available to measure certain definitional differences which may be significant. Furthermore, all of the percentage coverage figures are somewhat understated because no allowance is made for amounts received by persons not required to file tax returns. Such amounts, however, are probably relatively small, except for wages and salaries where they have been estimated roughly at about $\$ 1 \frac{1}{2}$ billion in $1952 . .^{10}$

\section{COMPARISON OF TAX-RETURN AND SURVEY COVERAGE}

Turning now to a comparison of Tables 2 and 3, relative income coverage is higher on tax returns than in the Census Bureau surveys for wages and salaries-96 per cent in 1952 tax returns and 91 per cent in the 1954 CPs; here differences of a few percentage points represent large absolute amounts. For interest plus dividends,

\footnotetext{
${ }^{8}$ In connection with the coverage of tax returns, it should not be inferred that differences between personal income and the amounts shown on tax returns consist entirely of underreporting of taxable income on income tax returns. Aside from possible differences in income definition between the two series that may not have been fully allowed for, some of the income omitted from tax returns would not be taxable even if properly reported, inasmuch as it would be offset by the credits and deductions allowable.

${ }^{2}$ For discussion of some of the remaining definitional differences, see Goldsmith, op. cit., pp. 356-358.

${ }^{10}$ Daniel M. Holland and C. Harry Kahn, "Comparison of Personal and Taxable Income," Federal Tax Policy for Economic Growth and Stability, Joint Committee on the Economic Report, 1955.
} 
the excess of tax return over survey relative coverage is very large ( 65 per cent compared with an estimated 23 per cent). For farm income, on the other hand, the survey coverage is much higher than that of tax returns ( 73 per cent compared with 40 per cent), and for rental income approximately the same proportion (about 60 per cent) is accounted for in the two sets of data. For nonfarm business and professional income, relative income coverage in the 1954 CPS ( 89 per cent) appears to be slightly higher than on 1951 tax returns ( 85 per cent), but comparisons for earlier periods indicate that the opposite was true of this income share.

In terms of absolute amounts, total money income not accounted for in the 1954 CPS, as noted earlier, was about \$43. billion. By excluding types of income not reportable on income tax returns (military and social security payments and "other" income) the CPS gap is decreased to about $\$ 36$ billion (based on Table 2). A comparable estimate for income undercoverage on 1954 tax returns is in the order of $\$ 24$ billion. Thus, undercoverage for corresponding income items is about $\$ 12$ billion more in the 1954 survey than on tax returns. This figure represents about 5 per cent of total family money income. For 1946, the corresponding figure estimated from Tables 2 and 3 is $\$ 10$ billion, or about 6 per cent.

Similar comparisons were also made for 1949. They indicated that income coverage on 1949 tax returns was about $\$ 5$ billion higher than for corresponding income items in the 1949 CPS-about 3 per cent of family money income in that year. ${ }^{11}$ Unfortunately it is not possible to make a comparison of this sort with the 1950 decennial census data for families and unattached individuals because data for separate major types of income are not available for these consumer units. ${ }^{12}$

${ }^{11}$ Income unaccounted for in the CPS of 1949 incomes was about $\$ 34$ billion (Table 1), of which approximately $\$ 6$ billion referred to income categories not reportable on tax returns. (Since reports for the separate types of income other than earnings were not requested in the 1949 survey, the $\$ 6$ billion figure is a rough estimate derived as shown for 1954 in Table 2 ). The remaining $\$ 28$ billion of income not accounted for in the survey compares with an estimate of $\$ 23$ billion for the corresponding amount for 1949 tax returns (derived as shown for 1954 in Table 3 ).

${ }^{12}$ In the 1950 Census of Population, total money income accounted for in the income size distribution of families and unattached individuals for 1949 is estimated by Herman Miller to have amounted to $\$ 155-159$ billion ("An Appraisal of the 1950. Census Income Data," Journal of American Statistical Association, March 1953, p. 40). This agrees closely with the $\$ 157$ billion coverage of the decennial census and with the $\$ 156$ billion coverage of the CPS for 1949 estimated here (Table 1). The available data do not make it possible to determine how much of the decennial census income total applied to income categories not reportable on tax returns, because tabulations of families and unattached individuals by size classes of separate major types of income were not made in the 1950 
What are the implications of these findings for the income sizedistribution data? The comparison suggests that after adjustments to allow for differences in the reporting unit and the definition of income, a distribution of tax returns by income level for any given year will probably be somewhat more heavily concentrated in the upper income ranges than a CPS distribution for families in the same year. Furthermore, the difference in the two distributions will be more marked for nonfarm families than for all families combined. In the case of farm-operator families the reverse will be the case, reflecting the higher coverage of farm income in Table 2 than in Table 3.

\section{Family Income Size Distributions from the $C P S$, the SCF, and $O B E$ Series}

Distributions for the year 1954 of families and unattached individuals by income level from the CPS, the SCF, and the OBE are compared in Table 4. The distributions from the two field surveys are classified by family money income brackets, whereas the classification in the OBE series is by family personal income. The latter includes nonmoney as well as money income items, and-as was explained earlier - its money income component differs from the surveys in income coverage and definition. The concept of family money income is just about the same in the two field surveys.

Definitions of families and unattached individuals (consumer units) agree in all three income size-distribution series, although the universe covered is somewhat narrower in the SCF than in the two other series. Families are defined as units of two or more persons related by blood, marriage, or adoption, and residing together. Unattached individuals ("unrelated individuals" in the CPS" reports and "one-person families" in the Federal Reserve Bulletin articles) are persons, others than institutional inmates, who are not living with any relatives; for example, they may be living alone or may be lodgers or servants with a private family.

In addition to the consumer-unit distributions shown in Table 4, income distributions are available from the SCF in terms of spending units. The spending unit, the basic interview and tabulating unit in

census. However, the similarity of the figures for total income coverage suggests that the decennial census income distribution of consumer units, like the 1949 CPS, probably accounted for about $\$ 5$ billion less income than did tax returns.

Miller points out that the income coverage of the 1950 decennial census income distributions is about $\$ 9$ billion higher for persons fourteen years old and over ( $\$ 168$ billion) than for families and unattached individuals ( $\$ 155-159$ billion) as a result of differences in the collection and editing of income data for persons and families (ibid., pp. 41-43). 
these surveys, is defined as related persons living in the same dwelling who pool their incomes for their major expenses. On the basis of this definition, about 5 to 6 million individuals or groups of individuals, who are related to the family head, are treated in recent years as separate units in the spending-unit tabulations. The SCF combines the income data for related spending units living in the same dwelling to obtain the family income distributions shown in Table 4.

\section{TABLE 4}

Comparison of Three Distributions of Families and Unattached Individuals by Income Level, 1954

\begin{tabular}{|c|c|c|c|c|c|c|c|}
\hline \multirow[b]{2}{*}{ INCOME LEVEL " } & \multicolumn{3}{|c|}{$\begin{array}{l}\text { FAMILIES AND UNATTACHED } \\
\text { INDIVIDUALS }\end{array}$} & \multicolumn{2}{|c|}{ FAMILIES } & \multirow{2}{*}{$\begin{array}{r}\text { UNATTACHED } \\
\text { CPS } \\
(6)\end{array}$} & \multirow{2}{*}{$\begin{array}{c}\text { INDIVIDUALS } \\
\text { SCF } \\
(7)\end{array}$} \\
\hline & $\begin{array}{l}\text { CPS } \\
(1)\end{array}$ & $\begin{array}{l}\text { SCF } \\
(2)\end{array}$ & $\begin{array}{r}\text { OBE } \\
(3)\end{array}$ & $\begin{array}{l}\text { CPS } \\
(4)\end{array}$ & $\begin{array}{l}\text { SCF } \\
(5)\end{array}$ & & \\
\hline & \multicolumn{7}{|c|}{ Number (millions) } \\
\hline $\begin{array}{l}\text { Under } \$ 1,000 \\
\$ 1,000-\$ 1,999 \\
2,000-2,999 \\
3,000-3,999 \\
4,000-4,999\end{array}$ & $\begin{array}{l}8.1 \\
6.5 \\
6.4 \\
7.4 \\
7.0\end{array}$ & $\begin{array}{l}4.3 \\
5.8 \\
5.6 \\
7.5 \\
6.8\end{array}$ & $\begin{array}{l}3.1 \\
5.4 \\
6.3 \\
7.4 \\
7.6\end{array}$ & $\begin{array}{l}3.7 \\
4.6 \\
5.0 \\
6.4 \\
6.5\end{array}$ & $\begin{array}{l}2.2 \\
4.3 \\
4.6 \\
6.6 \\
6.4\end{array}$ & $\begin{array}{l}4.4 \\
1.9 \\
1.4 \\
1.0 \\
0.5\end{array}$ & $\begin{array}{l}2.1 \\
1.5 \\
1.1 \\
0.9 \\
0.4\end{array}$ \\
\hline $\begin{array}{l}5,000-7,499 \\
7,500-9,999 \\
\$ 10,000 \text { and over } \\
\text { Total }\end{array}$ & $\begin{array}{r}10.3 \\
3.4 \\
2.5 \\
51.5\end{array}$ & $\begin{array}{r}11.6 \\
3.9 \\
3.5 \\
49.0\end{array}$ & $\begin{array}{r}12.8 \\
4.9 \\
3.7 \\
51.2\end{array}$ & $\begin{array}{r}9.9 \\
3.4 \\
2.4 \\
41.9\end{array}$ & $\begin{array}{r}11.3 \\
3.8 \\
3.4 \\
42.6\end{array}$ & $\begin{array}{l}0.4 \\
0.1 \\
0.1 \\
9.6\end{array}$ & $\begin{array}{l}0.3 \\
0.1 \\
0.1 \\
6.4\end{array}$ \\
\hline \multirow[t]{2}{*}{ Mean income } & $\$ 4,223$ & $\$ 4,900$ & $\$ 5,344$ & $\$ 4,765$ & $\$ 5,310$ & $\$ 1,850$ & $\$ 2,195$ \\
\hline & \multicolumn{7}{|c|}{ Percentage Distribution } \\
\hline $\begin{array}{r}\text { Under } \$ 1,000 \\
\$ 1,000-\$ 1,999 \\
2,000-2,999 \\
3,000-3,999 \\
4,000-4,999\end{array}$ & $\begin{array}{l}16 \\
12 \\
12 \\
14 \\
14\end{array}$ & $\begin{array}{r}9 \\
12 \\
11 \\
15 \\
14\end{array}$ & $\begin{array}{r}6 \\
11 \\
12 \\
14 \\
15\end{array}$ & $\begin{array}{r}9 \\
11 \\
12 \\
15 \\
16\end{array}$ & $\begin{array}{r}5 \\
10 \\
11 \\
16 \\
15\end{array}$ & $\begin{array}{r}45 \\
19 \\
14 \\
11 \\
5\end{array}$ & $\begin{array}{r}33 \\
23 \\
17 \\
14 \\
6\end{array}$ \\
\hline $\begin{array}{l}5,000-7,499 \\
7,500-9,999 \\
\$ 10,000 \text { and over } \\
\text { Total }\end{array}$ & $\begin{array}{r}20 \\
7 \\
5 \\
100\end{array}$ & $\begin{array}{r}24 \\
8 \\
7 \\
100\end{array}$ & $\begin{array}{r}25 \\
10 \\
7 \\
100\end{array}$ & $\begin{array}{r}23 \\
8 \\
6 \\
100\end{array}$ & $\begin{array}{r}26 \\
9 \\
8 \\
100\end{array}$ & $\begin{array}{r}4 \\
1 \\
1 \\
100\end{array}$ & $\begin{array}{r}5 \\
1 \\
1 \\
100\end{array}$ \\
\hline
\end{tabular}

" Family money income (before income taxes) for all columns except 3; for column 3, family personal income (before income taxes).

In the CPS and OBE series, families and unattached individuals include units living in quasi households (for example, large rooming houses or hotels) as well as households (the usual house or apartment), whereas the former group is excluded from the SCF. The quasi-household population includes about $1 \frac{1}{4}$ million con- 
sumer units, of which all but a few hundred thousand are unattached individuals, and of which about 600,000 reported money incomes under $\$ 1,000$ in the CPS for 1954 .

The most striking differences among the three income size distributions appear in the lowest income range, that is, the bracket under $\$ 1,000$. The proportion of consumer units in this bracket is 16 per cent in the CPS, about 10 per cent in the SCF (when the figures from that survey are roughly adjusted to include quasi-household units), and 6 per cent in the OBE series (where the relatively small proportion reflects in part the inclusion of nonmoney income items in the income definition and in part the more complete allowance for social security payments and other types of money income in the OBE series than in the surveys).

In contrast, the three series are in close agreement in the income range between $\$ 1,000$ and $\$ 5,000$. As Table 4 indicates, the proportions vary by at most only one percentage point within any $\$ 1,000$ bracket in this range.

The counterpart of the differences in figures for the lowest income bracket appears in the income range about $\$ 5,000$. The cPs shows 32 per cent of consumer units with incomes of $\$ 5,000$ or more, the SCF 39 per cent, and the OBE series 42 per cent. Above $\$ 10,000$ the corresponding percentages are 5, 7, and 7 .

The conclusion to be drawn from Table 4 is that the oBE and SCF distributions are in reasonable accord. The only noteworthy difference between the two series is in the lower tail of the distribution, and this can be explained in large part by the inclusion of nonmoney items of income in the OBE figures. The major differences that require explanation are those between the CPS and SCF data.

Turning to the separate figures for families and unattached individuals from the two surveys, Table 4 shows that in the under $\$ 1,000$ income bracket the CPS frequencies exceed those from the SCF by $1 \frac{1}{2}$ million for families and by about another $1 \frac{1 / 2}{2}$ million for unattached individuals (after allowing for quasi-household units). This difference is offset by a deficiency of 3 million in the CPs frequencies for families with incomes above $\$ 5,000$ compared with the SCF data.

This somewhat oversimplified summary of the differences between the two sets of sample data does not, of course, imply that the explanation of the differences is a simple one, for example, that a sizable group of families classified as having incomes of $\$ 6,000$ in the SCF are assigned $\$ 600$ in the CPS, as one reader of Table 4 suggested. Special factors making for the large difference in the survey figures for the under $\$ 1,000$ income bracket may operate 
apart from other more general factors that serve, figuratively speaking, to push some of the families in each income bracket in the CPS distribution up the income scale in the SCF.

One of these special factors is the difference between the two surveys shown in Table 4 in the total number of unattached individuals accounted for. The CPS total is $9 \frac{1}{2}$ million and the corresponding figure from the SCF about $7 \frac{1}{2}$ million (after allowance for quasi-household individuals). Apparently it is this difference that is responsible for the excess of $1 \frac{1}{2}$ million in the CPS frequency of unattached individuals in the income bracket under $\$ 1,000$. For multi-person families, on the other hand, the total number in the SCF is about 1 million higher than in the CPS (after making an allowance for the small number of families in quasi households).

To what extent do the family incomes in the surveys fail to reflect the composition of families during the income year? What effect does this factor have on both the total number of consumer units and the number in the lower ranges of the income scale?

In the CPS no reconstruction of consumer units is attempted. Data on incomes received during the calendar year are obtained only for those persons who constitute the consumer unit at the time of interview, usually April of the following year. For many consumer units this procedure proves satisfactory for family income classification purposes because no changes in composition take place over the period except for the birth of children.

But other changes in family composition are constantly occurring which cause difficulties in reconciling point-of-time figures for the number and size of families and annual income figures. ${ }^{13}$ For example, a Mrs. Jones, aged 67, who is living alone in her home in April 1955 because her husband died the preceding month, will report her $\$ 600$ of dividend income to the CPS enumerator and will be classified as an unattached individual with income under $\$ 1,000$ in Table 4. No account is taken of the $\$ 16,000$ earned by Mr. Jones during 1954 prior to his death.

Or a Johnny Smith, aged 23, who is living as a lodger with a private family in April 1955, having left his home town to start on his first full-time job a few months earlier, is also classified by the CPS as an unattached individual with income under $\$ 1,000$ in Table 4. He reports the $\$ 500$ he earned during 1954 while attending college in his home town, but no account is taken of the fact that his parents had supplied most of his support while he lived with

${ }^{18}$ This problem is discussed in some detail in Chapter 3 of "Income Distribution in the United States by Size, 1944-1950," a supplement to the Survey of Current Business, Dept. of Commerce, 1953. 
them during 1954. If his parents' family is enumerated, the family income that is reported will not include the $\$ 500$ earned by Johnny because he is not living with his parents at the time of interview.

In the SCF the Johnny Smiths are apparently treated in the same way as in the CPS. However, in the case of Mrs. Jones, the SCF enumerator will frequently obtain income information for the deceased Mr. Jones and thereby classify Mrs. Jones in a much higher income bracket than would his enumerator counterpart in the CPS. A discussion by the agencies conducting field surveys of the treatment of these and other instances of changes in family composition and their implication for the income size-distribution series is perhaps in order.

The lack of reconstruction of consumer units as they existed during the income year has probably introduced a net downward bias in the CPS income size-distribution series for the postwar period. Occasionally the bias will be upward, for example, if two groups of relatives (father plus mother, and their son plus his wife) double up after the close of the income year. In such cases the family income total which the CPS credits to one family unit actually represents, from the viewpoint of the income year, the combined income of two separate families. However, in the period of rapid family formation and economic growth following World War II, instances leading to a downward bias were doubtless much more numerous.

Since the bias may be significant, an effort should be made to measure its magnitude. At a minimum the Census Bureau might include questions in the CPS to determine how many of the unattached individuals had a different family status during all or part of the year to which their reports on income pertain. In the case of families a similar determination might be made at least for units reporting incomes of less than $\$ 1,000$. or $\$ 2,000$. $^{14}$

A reexamination of the CPS data, particularly for the lower end of the income scale, is suggested also by certain results from the Bureau of Labor Statistics Survey of Consumer Expenditures in 1950, which were discussed by Helen Lamale at the last meetings of the American Statistical Association..$^{15}$ In that survey, income and expenditure data were collected for consumer units as they existed during 1950, that is, for reconstructed units. The Johnny Smith

\footnotetext{
${ }^{14}$ Some questions designed to test the adequacy of the family definition for purposes of income measurement were included in the early Census Bureau surveys but have not been attempted in recent years.

${ }^{15}$ Helen Humes Lamale, "Methodology and Appraisal of Consumer Expenditure Studies," paper presented at 115th Annual Meeting of the American Statistical Association, New York City, December 28, 1955 (mimeographed).
} 
mentioned earlier, who was a newly formed unattached individual, is excluded from the survey, but his income during the time he lived at home is added to that of his parents if they fall in the sample. Similarly, other newly formed units or units dissolved in 1950 were not included in the BLS survey.

As Mrs. Lamale explains, partly as a result of this reconstruction and partly because of differences in the definition of families and single consumers, the BLS survey obtained "substantially fewer urban 1-person units than did the Census Bureau-4.2 million and 6.9 million respectively, and substantially more urban families of smaller average size -27.2 million families averaging 3.34 persons as compared with 25.4 million families averaging 3.49 persons."

Frequency distributions of urban consumer units by income level are not yet available from the BLS survey. There is every reason to believe, however, that the income distribution for the 4.2 million urban unattached individuals from the BLS survey will differ substantially from the CPS distribution of 6.9 million, that is, that the former will show many fewer units in the lower income brackets. The figures may suggest that the CPS definitions of families and unattached individuals, although adequate for other purposes, may require revision with respect to their point-of-time reference when used as a basis for classifying annual income data.

\section{Changes in Income Distribution}

\section{POST-WORLD WAR II DISTRIBUTIONS}

How do the various statistical series compare with respect to the changes they show in income distribution over time? Possible comparisons are limited to the post-World War II period because the CPS distributions by family money income level and the OBE distributions by family personal income level extend back only to 1944 (although Census Bureau wage and salary data are available also for 1939), and the SCF begin with 1945.

In Table 5 frequency and percentage distributions of consumer units by income level from the three data sources are compared for 1947 and 1954. By starting with 1947 rather than a year or two earlier, difficulties in income measurement encountered in the earlier surveys that stemmed partly from the large numbers of armed forces personnel returning to civilian life are eliminated. The percentage of total income accounted for in both the CPS and SCF was relatively larger in 1947 and later years than in the first few years of survey experience (see Table 1).

In terms of relative income coverage, survey data for the years 
TABLE 5

Comparison of Three Distributions of Families and Unattached Individuals by Income Level, 1947 and 1954

\begin{tabular}{|c|c|c|c|c|c|c|c|c|c|}
\hline \multirow[b]{2}{*}{ INCOME LEVEL " } & \multicolumn{3}{|c|}{$\begin{array}{c}\text { CURRENT POPULATION } \\
\text { SURVEY } \\
\end{array}$} & \multicolumn{3}{|c|}{$\begin{array}{c}\text { SURVEY OF CONSUMER } \\
\text { FINANCES } \\
\end{array}$} & \multicolumn{3}{|c|}{$\begin{array}{l}\text { OFFICE OF BUSINESS } \\
\text { ECONOMICS }\end{array}$} \\
\hline & 1947 & 1954 & $\begin{array}{l}1954 \text { as } \\
\text { percent- } \\
\text { age } \\
\text { of } 1947\end{array}$ & 1947 & 1954 & $\begin{array}{l}1954 \text { as } \\
\text { percent- } \\
\quad \text { age } \\
\text { of } 1947\end{array}$ & 1947 & 1954 & $\begin{array}{c}1954 \text { as } \\
\text { percent- } \\
\text { age } \\
\text { of } 1947\end{array}$ \\
\hline & \multicolumn{9}{|c|}{ Number (millions) } \\
\hline $\begin{array}{l}\text { Under } \$ 1,000 \\
\$ 1,000-\$ 1,999 \\
2,000-2,999 \\
3,000-3,999 \\
4,000-4,999\end{array}$ & $\begin{array}{l}8.0 \\
8.1 \\
9.4 \\
7.8 \\
4.5\end{array}$ & $\begin{array}{l}8.1 \\
6.5 \\
6.4 \\
7.4 \\
7.0\end{array}$ & $\begin{array}{r}101 \\
80 \\
68 \\
95 \\
156\end{array}$ & $\begin{array}{l}5.5 \\
7.8 \\
8.3 \\
7.1 \\
4.9\end{array}$ & $\begin{array}{l}4.3 \\
5.8 \\
5.6 \\
7.5 \\
6.8\end{array}$ & $\begin{array}{r}78 \\
74 \\
67 \\
106 \\
139\end{array}$ & $\begin{array}{l}3.7 \\
7.4 \\
8.5 \\
8.6 \\
5.7\end{array}$ & $\begin{array}{l}3.1 \\
5.4 \\
6.3 \\
7.4 \\
7.6\end{array}$ & $\begin{array}{r}84 \\
73 \\
74 \\
86 \\
133\end{array}$ \\
\hline $\begin{array}{c}5,000-9,999 \\
\$ 10,000 \text { and over }\end{array}$ & $\begin{array}{l}6.4 \\
1.1\end{array}$ & $\begin{array}{r}13.7 \\
2.5\end{array}$ & $\begin{array}{l}214 \\
227\end{array}$ & $\begin{array}{l}7.1 \\
1.8\end{array}$ & $\begin{array}{r}15.5 \\
3.5\end{array}$ & $\begin{array}{l}218 \\
194\end{array}$ & $\begin{array}{l}8.8 \\
2.0\end{array}$ & $\begin{array}{r}17.7 \\
3.7\end{array}$ & $\begin{array}{l}201 \\
185\end{array}$ \\
\hline Total & $\overline{45.3}$ & $\overline{51.5}$ & 114 & $\overline{42.5}$ & $\overline{49.0}$ & 115 & $\overline{44.7}$ & $\overline{51.2}$ & 115 \\
\hline \multirow[t]{2}{*}{ Mean income } & $\$ 3,261$ & $\$ 4,223$ & 130 & $\$ 3,780$ & $\$ 4,900$ & 130 & $\$ 4,126$ & $\$ 5,344$ & 130 \\
\hline & \multicolumn{9}{|c|}{ Percentage Distribution } \\
\hline $\begin{array}{l}\text { Under } \$ 1,000 \\
\$ 1,000-\$ 1,999 \\
2,000-2,999 \\
3,000-3,999 \\
4,000-4,999\end{array}$ & $\begin{array}{l}18 \\
18 \\
21 \\
17 \\
10\end{array}$ & $\begin{array}{l}16 \\
12 \\
12 \\
14 \\
14\end{array}$ & $\begin{array}{r}89 \\
67 \\
57 \\
82 \\
140\end{array}$ & $\begin{array}{l}13 \\
18 \\
20 \\
17 \\
11\end{array}$ & $\begin{array}{r}9 \\
12 \\
11 \\
15 \\
14\end{array}$ & $\begin{array}{r}69 \\
67 \\
55 \\
88 \\
127\end{array}$ & $\begin{array}{r}8 \\
17 \\
19 \\
19 \\
13\end{array}$ & $\begin{array}{r}6 \\
11 \\
12 \\
14 \\
15\end{array}$ & $\begin{array}{r}75 \\
65 \\
63 \\
74 \\
115\end{array}$ \\
\hline $\begin{array}{l}5,000-9,999 \\
\$ 10,000 \text { and over } \\
\text { Total }\end{array}$ & $\begin{array}{r}14 \\
2 \\
100\end{array}$ & $\begin{array}{r}27 \\
5 \\
100\end{array}$ & $\begin{array}{l}193 \\
250\end{array}$ & $\begin{array}{r}17 \\
\frac{4}{100}\end{array}$ & $\begin{array}{r}32 \\
7 \\
100\end{array}$ & $\begin{array}{l}188 \\
175\end{array}$ & $\begin{array}{r}20 \\
4 \\
100\end{array}$ & $\begin{array}{r}35 \\
7 \\
100\end{array}$ & $\begin{array}{l}175 \\
175\end{array}$ \\
\hline
\end{tabular}

"Family money income (before income taxes) for all except last three columns; for last three columns, family personal income (before income taxes).

1947 and 1954 are quite comparable. For the CPS this coverage was 82 per cent in 1947 and 84 per cent in 1954, and for the SCF, 89 and 92 per cent (Table 1).

All three series in Table 5 show a 30 per cent increase in the mean income of consumer units between 1947 and $1954 .{ }^{16}$ The level of the means, however, is lower in the SCF than in the OBE series, and still lower in the CPS, reflecting the differences discussed above.

${ }^{16}$ OBE mean incomes on a family money income basis comparable in definition to that used in the surveys increased by somewhat less ( 27 per cent). The extra few percentage points of increase shown in the OBE mean family personal incomes in Table 5 stem mainly from the inclusion of two items in family personal income excluded from family money income; the value of farm inventory change and the noncorporate nonfarm inventory valuation adjustment. Both were relatively large negative amounts in 1947 and either a positive or a much smaller negative amount in 1954. 
Although the pattern of changes in income distribution from 1947 to 1954 shown by the three series in Table 5 is basically similar, some points of difference may be noted. Most striking is the stability between 1947 and 1954 in the number of consumer units in the income range under $\$ 1,000$ in the CPS in contrast to the decline shown for that range in the SCF and estimated in the OBE series. If the CPS figures portray the actual situation, which seems unlikely, this stability in a period of generally rising incomes would be an exceedingly interesting finding. The very importance of the figures underlines the need for special Census Bureau studies designed to analyze the definitions and meaningfulness of the data for low-income groups.

Another difference in the series is the sharper increase from 1947 to 1954 in the proportion of consumer units in the income range above $\$ 4,000$ shown by the CPS than by the SCF or the tax-returnbased OBE series. The overstatement of the increase in the CPS figures probably reflects a higher relative coverage of business and professional income in the survey for 1954 than for $1947 .^{17}$

All three series show a basic stability in relative income distribution between 1947 and 1954. This is illustrated by the percentage shares of income accruing to families and unattached individuals in each quintile that have been computed for the three series in Table 6. Disregarding small changes in the percentages, the relative income shares show no perceptible trend in the 1947 to 1954 period.

An exception to this statement can, at first glance, be read into the figures in Table 6 in the case of the top quintile, mainly because the SCF shows a decrease in the relative income share of this fifth over the 1947-1954 period. It is likely, however, that the decrease in the survey figure is for the most part merely a reflection of sampling or other survey variations. Table 6 shows that practically all of the decline occurred between 1947 and 1950 and that a decline in that period is refuted by the 1947-1950 stability in the corresponding OBE figure. The OBE distributions through 1952, based in large part on data from federal individual income tax returns, are believed to provide more reliable estimates for the upper

\footnotetext{
${ }^{17}$ Data for separate major types of earnings are not available from the Census Bureau survey for 1947. However, when a comparison similar to Table 5 is made between 1946 and 1954, the CPS also shows a larger increase in the proportion of consumer units in the income range above $\$ 4,000$ than the oBE series (i.e. the percentage in that range more than doubled in the CPS and increased by about twothirds in the OBE distributions). As Table 2 indicates, relative coverage of business income in the CPS was much larger in 1954 than in 1946, and it may be inferred that this was also the case for 1954 versus 1947.
} 
TABLE 6

Percentage Distribution of Total Family Income among Quintiles of Families and Unattached Individuals Ranked by Size of Income, 1947 and 1950-1954

\begin{tabular}{|c|c|c|c|c|c|c|}
\hline QUINTILE ${ }^{a}$ & 1947 & 1950 & 1951 & 1952 & $19 \overline{53}$ & 1954 \\
\hline & \multicolumn{6}{|c|}{ Current Population Survey } \\
\hline $\begin{array}{l}\text { Lowest } \\
2 \\
3 \\
4 \\
\text { Highest }\end{array}$ & $\begin{array}{r}3.0 \\
10.5 \\
16.4 \\
23.3 \\
46.8\end{array}$ & $\begin{array}{r}2.6 \\
10.3 \\
17.3 \\
23.4 \\
46.4 \\
\end{array}$ & $\begin{array}{r}3.0 \\
11.0 \\
17.4 \\
24.1 \\
44.5\end{array}$ & \begin{tabular}{r|}
3.1 \\
10.8 \\
17.2 \\
24.1 \\
44.8 \\
\end{tabular} & $\begin{array}{r}2.8 \\
10.9 \\
17.5 \\
24.2 \\
44.6\end{array}$ & \begin{tabular}{r|}
2.8 \\
10.3 \\
17.1 \\
24.4 \\
45.4
\end{tabular} \\
\hline \multirow[t]{2}{*}{ Total } & $\overline{100.0}$ & $\overline{100.0}$ & $\overline{100.0}$ & $\overline{100.0}$ & $\overline{100.0}$ & $\overline{100.0}$ \\
\hline & \multicolumn{6}{|c|}{ Survey of Consumer Finances } \\
\hline $\begin{array}{l}\text { Lowest } \\
2 \\
3 \\
4 \\
\text { Highest }\end{array}$ & $\begin{array}{r}4.2 \\
10.3 \\
15.3 \\
22.1 \\
48.1 \\
\end{array}$ & \begin{tabular}{r|}
3.8 \\
11.1 \\
17.1 \\
23.2 \\
44.8 \\
\end{tabular} & $\begin{array}{r}3.8 \\
10.5 \\
16.9 \\
23.0 \\
45.8 \\
\end{array}$ & $\begin{array}{r}4.0 \\
11.3 \\
16.9 \\
23.0 \\
44.8 \\
\end{array}$ & $\begin{array}{r}4.1 \\
11.1 \\
16.8 \\
22.1 \\
45.9 \\
\end{array}$ & $\begin{array}{r}4.2 \\
11.3 \\
17.0 \\
23.0 \\
44.5 \\
\end{array}$ \\
\hline \multirow[t]{2}{*}{ Total } & $\overline{100.0}$ & $\overline{100.0}$ & $\overline{100.0}$ & $\overline{100.0}$ & $\overline{100.0}$ & $\overline{100.0}$ \\
\hline & \multicolumn{6}{|c|}{ Office of Business Economics Series } \\
\hline $\begin{array}{l}\text { Lowest } \\
2 \\
3 \\
4 \\
\text { Highest }\end{array}$ & $\begin{array}{r}5.0 \\
11.0 \\
16.0 \\
22.0 \\
46.0\end{array}$ & $\begin{array}{r}4.8 \\
10.9 \\
16.1 \\
22.1 \\
46.1 \\
\end{array}$ & $\begin{array}{r}5.0 \\
11.3 \\
16.5 \\
22.3 \\
44.9\end{array}$ & $\begin{array}{r}4.9 \\
11.4 \\
16.6 \\
22.4 \\
44.7 \\
\end{array}$ & $\begin{array}{r}4.9^{\mathrm{b}} \\
11.4^{\mathrm{b}} \\
16.6^{\mathrm{b}} \\
22.4^{\mathrm{b}} \\
44.7^{\mathrm{b}}\end{array}$ & $\begin{array}{r}4.9^{b} \\
11.4^{b} \\
16.6^{b} \\
22.4^{b} \\
44.7^{b}\end{array}$ \\
\hline Total & $\overline{100.0}$ & $\overline{100.0}$ & $\overline{100.0}$ & $\overline{100.0}$ & $\overline{100.0}$ & $\overline{100.0}$ \\
\hline
\end{tabular}

a Ranking, except for lowest bank of figures, is by family money income (before income taxes); for lowest

bank, by family personal income (before income taxes).

${ }^{b}$ Preliminary.

ranges of the income scale than do the small samples from the surveys.

A check on the survey findings for the upper-income groups on the basis of data from individual income tax returns has not yet been made for the period after 1952. This type of check will be conducted by the OBE as tabulations of tax returns for later years become available.

\section{LONGER-RUN CHANGES IN INCOME DISTRIBUTION}

In order to view the postwar income distributions in perspective, they are compared with prewar estimates in Tables 7 and 8. The OBE income distributions are included for selected years since 1944 and prewar estimates are shown for 1941, 1935-1936, and 1929.

Major findings from these tables have been discussed in an article on "Size Distribution of Income since the Mid-Thirties." 18 How-

${ }^{18}$ Selma Goldsmith, George Jaszi, Hyman Kaitz, and Maurice Liebenberg, Review of Economics and Statistics, February 1954. 


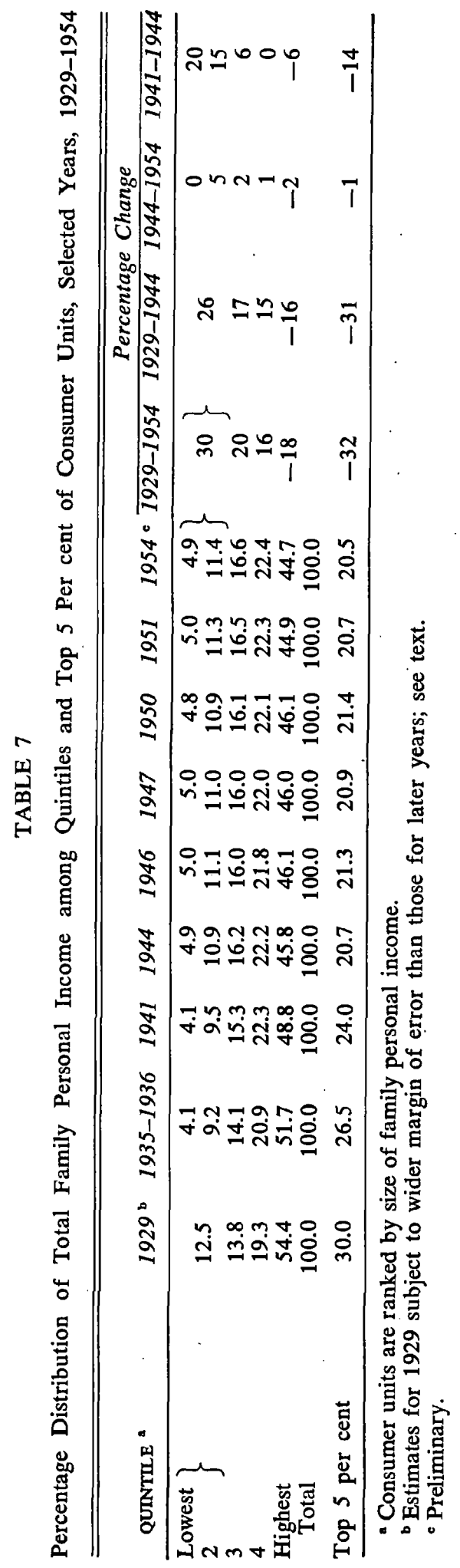




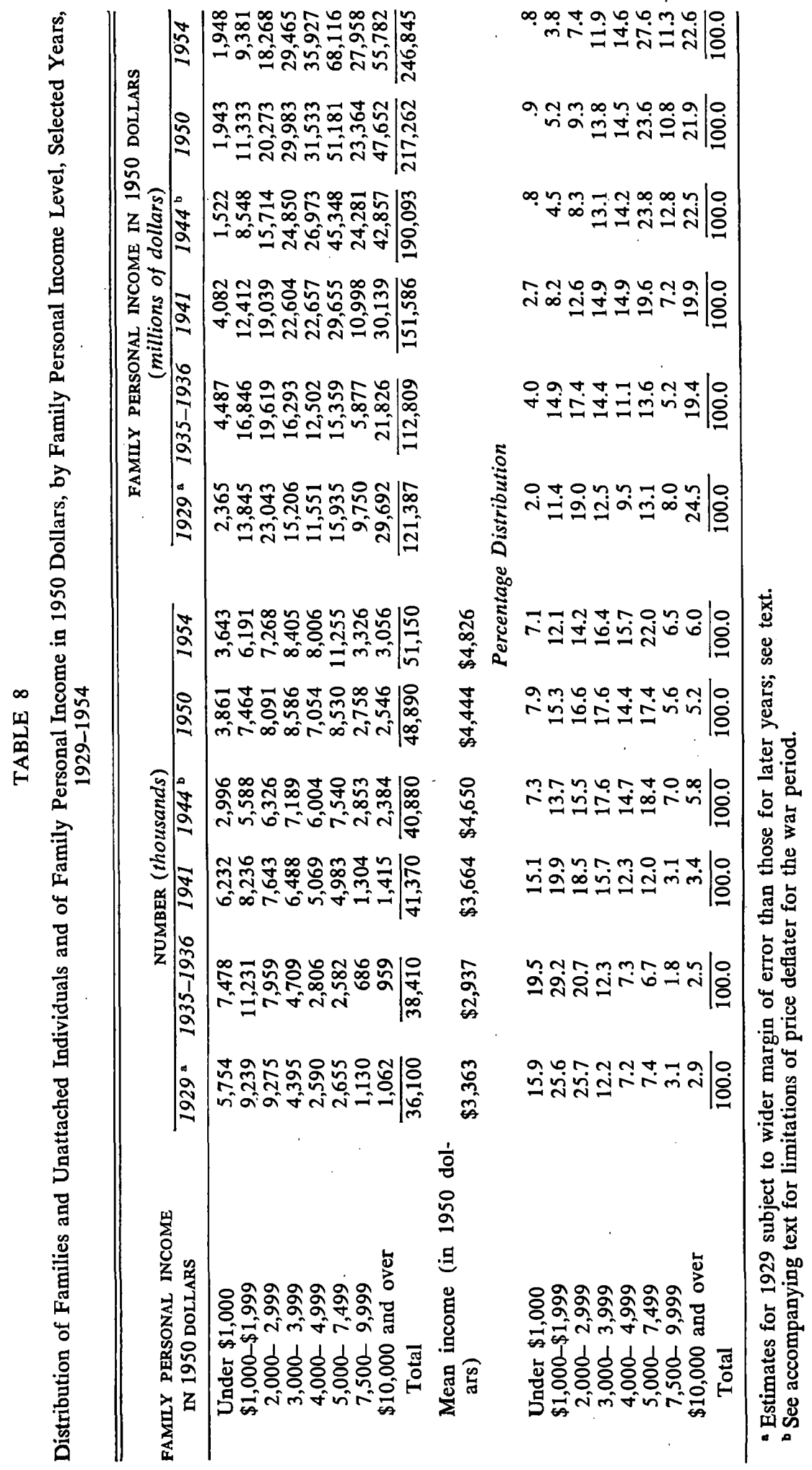


ever, the present tables expand the period for which comparisons are made by adding estimates for recent years for which OBE distributions were not available when the earlier article was written and by including rough estimates for 1929 .

Limitations of the family income distribution statistics for 19351936 and 1941 were described in the earlier article. Although the estimates for those years, 'based on data from field surveys and from income tax returns, incorporate a number of adjustments to make them as comparable as possible with the postwar series, full adjustment for definitional and other differences was not feasible.

For 1929 , limitations in both the basic data and in the adjustments made here are even greater. Unlike 1935-1936, 1941, and postwar years, there was no nationwide sample field survey of family incomes in 1929 on which to base the income distribution estimates. Instead, the Brookings Institution constructed a 1929 distribution for families and unattached individuals by combining a variety of different sets of income statistics for persons (for example, for wage earners and farmers) and then converting them to a family-unit basis. ${ }^{19}$ The Brookings distribution is admittedly rough, particularly for the lower end of the income scale.

At the upper end the Brookings study, like those for later years, incorporated data from federal individual income tax returns. However, capital gains and losses were included in the income definition in that study, in contrast to their exclusion from later estimates. This had the effect of materially exaggerating the relative share of income received by the upper segment of consumer units compared with income-distribution data for following years.

In Tables 7 and 8, the Brookings distribution for 1929 has been adjusted to remove capital gains and losses. This adjustment and a less important one relating to understatement of business income on tax returns are described in the technical notes in the Appendix. The adjustments were necessarily rough, but they serve to make the estimates for 1929 more comparable with those for recent years and thereby make it possible to avoid some mistaken conclusions drawn by students who compared postwar income distributions directly with the Brookings figures. Although the present figures for 1929 are more comparable with respect to capital gains and losses than the unadjusted figures, they are essentially the Brookings figures which, in the absence of basic family income data for that year, are to be regarded as rough approximations to the actual situation.

\footnotetext{
${ }^{20}$ Maurice Leven, Harold G. Moulton, and Clark Warburton, America's Capacity to Consume, Brookings Institution, 1934.
} 
Table 7 presents estimated percentage shares of family personal income accruing to successive quintiles of families and unattached individuals for selected years back to 1929. Most prominent are decreases in the relative shares accruing to the top quintile of consumer units between 1929 and 1944, which were accompanied by increases in the shares of all the other quintiles. For the two lowest fifths, relative gains were largest between 1941 and 1944. The changes in relative income position of the various quintiles prior to 1944 are in marked contrast to the stability of relative income distribution in the postwar period.

The reader is referred to the article on "Size Distribution of Income since the Mid-Thirties" for a discussion of factors underlying these changes in relative income distribution. One of the most important of them-the narrowing of wage differentials since 1939 -is discussed in Miller's paper in this volume.

One point from the earlier paper that bears repetition is the warning that the amount of change in relative income distribution depends in part on the particular income definition used. Alternative calculations on a national income basis (differing from personal income by including undistributed corporate profits and corporate profits taxes, and by excluding government transfer payments and government interest) indicate that the decrease from 1929 to the present in the income share of the top 5 per cent was substantially less than is shown on a personal income basis in Table 7.

Another point that should be stressed is that the decline in the relative income share of the top 5 per cent of consumer units over the twenty-five-year period covered by Table 7-which accounted for most of the decline in the relative share of the top quintile-is to a large extent a reflection of a comparable decline shown by statistics from federal individual income tax returns. This can best be illustrated by comparing the 1929 and the postwar mean incomes underlying the figures on the relative income shares of the top income sector.

In 1952, for example, the latest year for which detailed tabulations of tax return statistics are available, the mean family personal income of all consumer units combined, in current dollars, was 2.2 times as large as in 1929 ( $\$ 5,120$ compared with $\$ 2,340)$. For the top 5 per cent of consumer units, the corresponding means that underlie Table 7 are estimated at $\$ 21,030$ in 1952 and $\$ 14,030$ in 1929 , a ratio of 1.5 . The decline in the relative income share of the top 5 per cent of consumer units shown in Table 7 is, of course, simply a reflection of this smaller ratio.

Turning to the income tax return statistics, which were the basic 
series used in constructing the estimates for the upper-income segment of the consumer-unit distributions in both the prewar and postwar periods, it is immediately apparent that comparisons cannot be made between 1929 and any World War II or postwar year in terms of a "top 5 per cent of income tax returns." The universe of income tax returns differs too radically in the two periods, largely as a result of changes in filing requirements: only 4 million individual income tax returns were filed in 1929, almost 57 million in 1952. Nor can one compare 1929 with a postwar year in terms of the mean incomes reported on those particular income tax returns that underlie the top 5 per cent of consumer units. Aside from other difficulties, the description of the way the Brookings study combined individual income tax returns into family units is not sufficiently detailed to make it possible to determine precisely which income tax returns from which income brackets comprise the top tail of consumer units in the Brookings distribution.

In 1952 the top 5 per cent of families and unattached individuals consisted of consumer units with family personal incomes of approximately $\$ 11,480$ and over, and in 1929 of those with $\$ 5,690$ and over. This suggests that the ratio of the mean income reported on individual income tax returns with incomes of $\$ 10,000$ and over in 1952 to the mean reported on tax returns with incomes of $\$ 5,000$ and over in 1929 may be taken as roughly equivalent to the corresponding ratio for the top 5 per cent of consumer units. This tax-return ratio is found from Statistics of Income to be 1.3 when statutory capital gains are included in income, and 1.5 when such net gains are excluded and the tax returns reranked, as best one can, by size of income exclusive of net capital gains. ${ }^{20}$ This latter ratio is the same as that noted above for the top 5 per cent of consumer units.

In other words, a comparison of the top tail of the income distributions developed for postwar years by the OBE with that developed for 1929 by the Brookings authors (as adjusted here) reveals the basic pattern of changes reported in Statistics of Income in the structure of the upper-income segment of individual income tax returns. It is in this sense that the statistics in Tables 7 and 8 should be interpreted. A detailed reworking of the 1929 estimates to introduce greater comparability with the family personal income distributions

${ }^{20}$ The reranking is described for 1929 in the notes to Tables 7 and 8 , and for 1952 in Survey of Current Business, March 1955, p. 10. A further adjustment in 1929 , for comparability with 1952 , to add statutory deductions to statutory net income exclusive of capital gains raised the estimated mean income of tax returns having incomes of $\$ 5,000$ or more, but the ratio of the 1952 mean to this adjusted 1929 mean remained at a rounded 1.5 . 


\section{CENSUS INCOME DISTRIBUTIONS}

for later years, particularly with respect to methods of combining tax returns into family units and assumptions relating to income understatement, might result in significant revisions of the figures. The changes since 1929 in mean incomes and income shares of the upper sector of the income distribution might be most affected. Such a reworking of the 1929 figures has not been attempted here.

Frequency distributions of families and unattached individuals by income level, in constant (1950) dollars, are presented in Table 8. The most interesting contrast is between the estimates for 1929 and 1954. Compared with the 12 million consumer units (onethird) with incomes (in 1950 dollars) of $\$ 3,000$ or more in 1929 , 34 million 1954 consumer units (two-thirds) were in that income range. In real income brackets above $\$ 4,000$, there were 21 per cent of consumer units in 1929 and 50 per cent in 1954, and above $\$ 5,000,13$ per cent in the earlier year and 35 per cent in the latter.

Most of the upsweep in real incomes is shown in Table 8 to have occurred in the period up to 1944 . However, this is somewhat exaggerated by the price deflators used to derive the constant-dollar figures. The available price indexes do not fully reflect the actual rise in prices that took place during World War II, and hence overstate the price rise in early postwar years. ${ }^{21}$ As a result, the actual shift of consumer units up the real income scale is probably somewhat less during the war and somewhat greater in the early postwar period than is shown here.

\section{Appendix: Technical Notes to Tables}

\section{TABLE 1}

\section{Column 1}

From Survey of Current Business, Dept. of Commerce, July 1955, Table 3.

\section{Column 2}

Column 1 minus following items (figures refer to amounts estimated for 1952, in billions of dollars): military nonmoney pay plus money pay of persons not returned to civilian life by end of year who lived on post (6.5); earnings of persons who entered armed forces or died during year (1.2) ; dividends, interest, rent, and business income received by fiduciaries, less income distributed to individuals by fiduciaries $(0.6)$; interest, dividends, rents, and transfer payments received by nonprofit institutions (1.3); employer contributions to private pension and welfare funds (4.0); miscellaneous items (0.1).

${ }^{2}$ Limitations of the price deflators are discussed in Goldsmith, Jaszi, Kaitz, and Liebenberg, op. cit. 


\section{Column 3}

Column 2 minus following items (figures refer to amounts estimated for 1952, in billions of dollars): nonmoney civilian farm and nonfarm wages and salaries (1.8); value of food and fuel produced and consumed on farms by members of farm operator families and gross rental value of farm homes (3.4); net rental values of owner-occupied nonfarm homes (4.2); imputed interest (5.3); noncorporate nonfarm inventory valuation adjustment $(0.2)$; value of change in farm inventories (0.6); accrued interest on unredeemed United States government bonds (0.7); miscellaneous items (1.5); and plus the following items: personal contributions for social insurance (3.8); estimated net income from roomers and boarders in private homes $(0.8)$; and estimated periodic payments received by individuals from life insurance companies (1.0). For 1945, the higher figure in column 3 covers also estimated military pay received in 1945 by persons who returned to civilian life during the first three months of 1946, which is included here to conform in coverage with the census survey conducted in April 1946; the lower figure which excludes the pay of these returnees is comparable to the coverage of the SCF, conducted earlier in 1946.

\section{Column 4}

Derived from 1941 survey as explained in my paper in Volumn Thirteen (1951) of Studies in Income and Wealth, notes to Table 2.

\section{Column 5}

Derived from CPS (Census Bureau nonfarm plus Bureau of Agricultural Economics farm survey for 1946) by multiplying tabulated number of consumer units in each income bracket by an estimated average income for the bracket. According to Census Bureau calculations, the aggregate amounts accounted for in these surveys are 1 or 2 percentage points higher than those shown here when CPS distributions of persons (rather than consumer units) are multiplied by estimated means for the several income brackets.

\section{Column 6}

Product of figures from Board of Governors of the Federal Reserve System on mean income of families and unattached individuals and number of such consumer units in each year. Excludes consumer units in quasi households.

\section{TABLE 2}

\section{Column 1}

From Survey of Current Business, July 1955, Tables 1, 3, and 35.

\section{Column 2}

Column 1 adjusted to subtract or add the appropriate items listed in notes to Table 1 , columns 2 and 3 , and to transfer certain items from one income category to another to match as closely as possible the 


\section{CENSUS INCOME DISTRIBUTIONS}

definitions in the census field surveys. In accordance with the census income classification, military wages and salaries of persons returned to civilian life are included under military payments in 1946, but under wages and salaries in 1954. For further details, see my paper in Volume Thirteen (1951) of Studies in Income and Wealth, notes to Table 3.

\section{Column 3}

For 1946, ibid., Table 3. For 1954, figures other than in parentheses derived by multiplying distributions of consumer units by size classes of each of four major types of income (Current Population ReportsConsumer Income, Bureau of the Census, Series P-60, No. 20, Table 11) by estimated means for each class. Figures in parentheses derived by multiplying amount for 1954 in column 2 by percentage coverage for 1946 in column 5, as explained in text.

TABLE 3

\section{Columin 1}

From Survey of Current Business, July 1955, Tables 1, 3, and 35.

\section{Column 2}

Column 1 adjusted as follows (figures refer to amounts estimated for 1952, in billions of dollars):

Wages and salaries. Column 1 minus military nonmoney pay (1.4), nontaxable items of military money pay (2.9), and nonmoney civilian farm and nonfarm wages and salaries (1.8); and plus employee contributions for social insurance (3.5), directors', jury, etc. fees (0.1), and amount classified as business income in column 1 that is estimated might be reported on individual income tax returns as wages and salaries (1.6).

Business and professional income. Column 1 minus value of food and fuel produced and consumed on farms and gross rental value of farm homes (3.9), value of change in farm inventories (0.6), noncorporate nonfarm inventory valuation adjustment $(0.2)$, business income received by fiduciaries $(0.1)$, and amount of nonfarm business income that is estimated might be reported on individual income tax returns as wages or salaries (1.6); plus expenses on owner-occupied farm homes, which are not deductible on individual income tax returns (0.7), and self-employed persons' contributions for social insurance (0.2). Separate amounts for nonfarm and farm business income shown for 1951 were derived by adjusting the OBE amounts for the two separate categories (Survey of Current Business, July 1955, Tables 1 and 35 ), as described above, and transferring patronage refunds and stock dividends paid by farmers' cooperatives from the nonfarm to the farm category.

Interest. Column 1 minus imputed interest (5.3), interest received by nonprofit institutions $(0.2)$, by fiduciaries $(0.3)$ and by corporate 
pension funds $(0.2)$, accrued interest on unredeemed United States government bonds (0.7), and interest on tax-exempt securities (0.3).

Dividends. Column 1 minus dividends received by nonprofit institutions $(0.2)$, by fiduciaries (1.7), by corporate pension funds $(0.1)$, and by mutual insurance companies $(0.2)$.

Rental income. Column 1 minus imputed net rental value of owneroccupied nonfarm homes (4.2), and rent received by nonprofit institutions and fiduciaries $(0.4)$.

\section{Column 3}

Reported on federal individual income tax returns, Statistics of Income, Treasury Dept., Part 1, 1946, and preliminary report for 1952. For 1951, the figure for farm income is the net amount reported as sole proprietorship income from farming on 1951 tax returns (ibid., 1951) plus an estimate of partnership farm income (derived by extrapolating farm income reported on 1947 partnership tax returns by the reported amounts of proprietorship net income from farming). Nonfarm business and professional income in 1951 was obtained by subtracting the farm income figure from the reported total of business, professional, and partnership net income.

\section{Column 4}

Column 3 adjusted as follows (figures refer to amounts estimated for 1952 , in billions of dollars):

Wages and salaries. Column 3 minus reported receipts in Alaska and Hawaii (0.8), and plus reported wages not subject to withholding (less than 0.1 ).

Business and professional income. Column 3 minus reported receipts in Alaska and Hawaii (0.1) and interest, dividends, and rent reported as business income on tax returns that are included under the propertyincome categories in columns 1 and $2(0.3)$; plus depletion not deducted in columns 1 and $2(0.2)$.

Interest. Column 3 minus reported receipts in Alaska and Hawaii, plus receipts by partnerships that are included under interest in columns 1 and 2, plus interest reported under miscellaneous income on tax returns (each less than 0.1 ).

Dividends. Column 3 minus reported receipts in Alaska and Hawaii (less than 0.1 ), plus receipts by partnerships that are included under dividends in columns 1 and $2(0.1)$, plus dividends reported under miscellaneous income on tax returns (less than 0.1 ).

Rental income. Column 3 minus reported receipts in Alaska and Hawaii (less than 0.1 ), plus rents reported as business income on tax returns that are included under rents in columns 1 and $2(0.1)$.

Note. For derivation of most of the adjustments in columns 2 and 4 , and for discussion of areas for which full adjustment could not be made, 


\section{CENSUS INCOME DISTRIBUTIONS}

see my paper in Volume Thirteen (1951) of Studies in Income and Wealth, notes to Table 8 . In deriving the various items of fiduciary income, the procedures described in Volume Thirteen were revised in all years to incorporate statistics for nontaxable fiduciary income tax returns for 1952. These data are the first available for this category of tax returns since 1939 (see Statistics of Income, Part 1, for 1952). The methodology described in Volume Thirteen was also revised to allow for postwar changes in the tax treatment of military pay, and was improved by introducing adjustments (in col. 2) to allow for property income received by corporate pension funds and by eliminating (in col. 2) subtractions which had been made in Volume Thirteen for civilian earnings of persons who died or entered the armed forces during the year.

TABLE 4

Columns 1, 4, 6

Derived from Current Population Reports-Consumer Income, Series P-60, No. 20, Table 1.

Columns 2, 5, 7

From Board of Governors, Federal Reserve System.

Column 3

Survey of Current Business, June 1956, Table 2, p. 10.

TABLE 5

1947

CPS column derived from Current Population Reports-Consumer Income, Series P-60, No. 5, Table 1. Survey of Consumer Finances column derived from data from Board of Governors, Federal Reserve System. OBE column from Survey of Current Business, June 1956, Table 4, p. 12. 1954

See notes to Table 4 .

TABLE 6

CPS

Interpolated graphically from Lorenz curve of distribution of consumer units by family money income levels. Percentage distributions of consumer units by income level from Table 1 of Current Population Reports-Consumer Income, Series P-60, Nos. 5, 9, 12, 15, and 20 (similar data for 1953 furnished by Census Bureau). For each year, aggregate family money income in each income bracket was estimated by multiplying the number of consumer units in the bracket by an estimated mean income. For the highest income bracket in the census tabulations ( $\$ 10,000$ and over in 1947 and 1950, $\$ 15,000$ and over in 1951 , and $\$ 25,000$ and over in 1952 to 1954 , where the census enumerators did not ask for amounts of income) errors of estimation in these means 
may underlie some of the small changes in income shares shown in the table for the top quintile.

\section{$S C F$}

Interpolated graphically from Lorenz curves. Percentage distributions of consumer units and of aggregate family money income by family money income level from Board of Governors, Federal Reserve System.

\section{$O B E$}

From Survey of Current Business, as follows: 1947, Income Distribution in the United States by Size, 1944-1950, Supplement, 1953, Table 3, p. 81; 1950-1951, March 1955, Table 9, p. 24; 1952-1954, June 1956, Table 5, p. 12.

\section{TABLES 7 AND 8}

\section{9}

Distribution for 1929 is not part of the official income distribution series of the OBE which begins with 1944. Percentage shares in Table 7 interpolated from income distribution for 1929 which was derived as described below. The 1929 distribution in terms of 1950 prices in Table 8 was obtained by applying the OBE price index used for deflating personal consumption expenditures to the distribution of current dollar incomes, assuming that the same index applied to all income groups. (For statistical procedure, see Income Distribution in the United States by Size, 1944-1950, n. 12, p. 38.)

The 1929 distribution of families and unattached individuals by family personal income level was derived by making two adjustments in the Brookings Institution estimates for that year (Maurice Leven, Harold G. Moulton, and Clark Warburton, America's Capacity to Consume, The Brookings Institution, 1934). The first of these was to subtract net capital gains from the Brookings figures. Of the total income of $\$ 92,950$ million accounted for in the Brookings distribution, net capital gains (gains less losses) amounted to $\$ 6,200$ million or almost 7 per cent (ibid., p. 167). The relative importance of this item was of course very much higher in the upper income ranges. For example, it is estimated that such net gains accounted for 33 per cent of the total income of families and unattached individuals with 1929 incomes over $\$ 50,000$ in the Brookings figures.

A second adjustment, which also served to lower the income share of top income groups, was to reduce the amount added by the Brookings authors for understatement of business income on income tax returns. The amount that had been added was relatively much higher than the comparable adjustment for later years.

Capital gains. The adjustment to remove capital gains was based on the following tabulations of federal individual income tax returns which were available for 1929: (1) aggregate amount of net capital gain segre- 
gated for tax at $12 \frac{1}{2}$ per cent, by net income classes (net income being defined on tax returns to include net capital gains); (2) number of returns with net capital gain segregated for tax at $121 / 2$ per cent, by size classes of such net capital gain (for all returns with net incomes of $\$ 5,000$ or more) ; (3) aggregate amount of net capital gain segregated for tax at $12 \frac{1}{2}$ per cent, by size classes of such net capital gain (for all returns with net incomes of $\$ 5,000$ or more); (4), (5), and (6) corresponding tabulations for net capital gain other than segregated for tax at 121/2 per cent. (Statistics of Income for 1929, pp. 11, 12, 75).

Step 1 was to estimate the number of income tax returns with net capital gains at each net income bracket above $\$ 5,000$. This was done by constructing, for returns with net capital gain segregated for tax at $12 \frac{1}{2}$ per cent, a cross-classification table in which the number of returns with such gain and the aggregate amount of such gain were each distributed by size classes of net capital gain (the columns in the table) and cross-classified by size classes of net income (the rows in the table); and by constructing a corresponding table for returns with net capital gain other than segregated for tax at $12 \frac{1}{2}$ per cent. These crossclassification tables were filled in as follows:

a. For the first table, the figures from tabulations 2 and 3 above provided the column totals for numbers of returns and amounts of gain, and those from tabulation 1 the row totals for amounts of gain. Similarly, the margins of the second table were filled in from tabulations 4,5 , and 6 .

b. The cells in each of the two tables were filled in, initially, by distributing each column total among the rows in proportion to the corresponding distribution of returns in that capital-gain class in 1950. The 1950 distributions were based on actual cross-classifications of tax returns with capital gain for that year. This yielded preliminary estimates of the number of returns and aggregate amount of net capital gain in each cell. By adding entries within a row, preliminary estimates were obtained of the total number of returns and aggregate amounts of capital gain by net income classes.

c. The latter amounts were compared with the actual row totals from tabulations 1 and 4 and found to be too high in the net income range between $\$ 100,000$ and $\$ 500,000$ and too low in most lower and higher income brackets. To correct for this, the amounts of capital gain in the various cells were adjusted, and at the same time the numbers of returns with capital gain in corresponding cells were adjusted proportionately, so that the entries in the cells would total both to the column and the row totals from tabulations 1 through 6.

d. The estimated number of returns with capital gain in each net income class was derived by summing the adjusted numbers in the various cells within each row and adding the results for the two crossclassification tables. It was not possible to allow for instances in which both segregated and unsegregated capital gains may have been reported on the same tax return. 


\section{CENSUS INCOME DATA}

Step 2 was to shift the adjusted number of returns in each cell in $c$ above, i.e. returns within given ranges of net income and of capital gain, to brackets of income exclusive of capital gain. This was done on the basis of formulas for subtracting through a cross-tabulation that had been developed for a corresponding purpose by the OBE (Income Distribution in the United States by Size, 1944-1950, n. 9, p. 36). The subtraction yielded a new cross-classification table in which returns with capital gain were classified by net income brackets and, within each such bracket, by size classes of income exclusive of capital gain. This crossclassification covered the various net income brackets above $\$ 5,000$. On the basis of these figures, corresponding estimates were extrapolated for the lower net income range, which were then adjusted to meet the control totals for this range from tabulations 1 and 4 .

Step 3 was to estimate the number of families and unattached individuals with capital gain included in the various family income brackets in the Brookings study. The work of estimating the amounts of capital gain included in total income in corresponding family income brackets had already been done by Simon Kuznets (Shares of Upper Income Groups in Income and Savings, National Bureau of Economic Research, 1953, p. 220). The Brookings authors presented estimates of such amounts by brackets of individuals' income (Leven, Moulton, and Warburton, op. cit., pp. 206, 208), and Kuznets, for purposes of his study, transformed these into brackets of family income.

Capital gains included in the Brookings distribution totaled substantially more than was reported on income tax returns because the Brookings authors, in developing the upper tail of the family income distribution from tax returns, had increased capital gains reported in the $\$ 5,000$ and over net income range by 65 per cent to allow for underreporting; they had also raised the capital gain figures from tax returns in the range below $\$ 5,000$ to allow for the fact that the coverage of tax returns was incomplete in the lower income range because of the high filing requirements of 1929 (ibid., p. 167). The Brookings authors do not state that the numbers of units with capital gains were raised correspondingly, but it appears from what they say that this must have been the case. Accordingly, the ratio of the amount of capital gain in each income bracket in the Brookings distribution (Kuznets, op. cit., p. 220, columns 1 plus 5 ) to the amount in the corresponding bracket reported on tax returns (tabulations 1 plus 4 above) was applied to the number of returns with capital gain in the income bracket derived in step 1d above, to obtain the estimated number of consumer units with capital gain in the various family income brackets in the Brookings distribution.

Step 4 was to estimate the number of families and unattached individuals in various size classes of family income exclusive of capital gain. This was done by distributing the number of consumer units in each family income bracket from step 3 in proportion to the distribution of 


\section{CENSUS INCOME DISTRIBUTIONS}

frequencies by size classes of income exclusive of capital gain that had been developed for the corresponding net income bracket in step 2, and then summing the results over all family income brackets.

Step 5 was to adjust the Brookings distribution to remove capital gains. The adjustment in frequencies was made by subtracting the numbers of families and unattached individuals with capital gain in the various family income brackets derived in step 3 from the Brookings frequencies (Leven, Moulton, and Warburton, op. cit., p. 227), and then adding the numbers in the various brackets of family income exclusive of capital gain from step 4. Correspondingly, estimated amounts of aggregate income inclusive of capital gain received by consumer units with capital gain were subtracted from the Brookings total income figures (ibid., p. 229 ), and aggregate amounts of income exclusive of capital gain received by these units were added, in the appropriate income brackets. Approximately $\$ 7$ billion of capital gain was subtracted from the Brookings income total by this procedure, $\$ 41 / 2$ billion of which was subtracted in the income range above $\$ 50,000$.

Capital losses. No adjustment was necessary for capital loss segregated for tax credit at $12 \frac{1}{2}$ per cent because such losses had not been deducted by taxpayers in 1929 in determining their net income. (Instead, persons with these losses applied their tax credit directly to their computed tax liability.) The required adjustment for capital loss therefore related only to losses other than those segregated for tax credit.

It was not considered worthwhile to shift the Brookings income distribution to add nonsegregated capital losses except, as noted below, in the deficit class. The losses that were included in the Brookings distribution were relatively small as compared with the gains. Moreover, for the income range under $\$ 5,000$ the description of methodology in the Brookings study suggests that capital losses may not have been taken into account at all.

In the deficit class, where Brookings included the $\$ 0.8$ billion of capital losses reported on deficit tax returns, a rough allocation was made of the estimated number of consumer units with capital losses to brackets of family income exclusive of such losses. The allocation was based on a tabulation of 1929 tax returns with nonsegregated capital loss and with incomes of $\$ 5,000$ or more by size of such capital loss. (Statistics of Income for 1929, pp. 11, 16.) The shift of units out of the deficit bracket had the effect of adding $\$ 0.8$ billion of income to the Brookings figures. As indicated, a similar allocation was not made for consumer units in the income range above $\$ 5,000$. Instead, the amounts of capital loss reported in these brackets were netted by the Brookings authors and by Kuznets against capital gains in corresponding brackets, and it was these net amounts that were used in steps 3 and 5, above. The omission in this range of an explicit adjustment to remove capital losses, which would have shifted a small proportion of consumer units to higher 
family income brackets, introduced some error in the estimated income size distribution for 1929, but it is probably small.

Understatement of business income. The Brookings authors increased the number of income tax returns reporting net business or partnership earnings in each business earnings bracket above $\$ 5,000$ by 65 per cent in order to allow for understatement of this type of income on 1929 tax returns (Leven, Moulton, and Warburton, op. cit., p. 187). A correction factor more nearly comparable with that used by the OBE for later years is 15 per cent. Accordingly, an adjustment was made to shift some consumer units down the income scale to introduce closer comparability with the series for later years.

The increase in the number of tax returns that had been introduced in the Brookings study was available for each size class of business earnings above $\$ 5,000$ (ibid., Table 23, p. 187). Three-fourths of these frequencies-assumed to be the excess in the Brookings adjustmentwere shifted to size classes of total income (earnings plus other types of income) on the basis of ratios of total income to earnings available for the various earnings brackets (ibid., Table 35, p. 221). The resulting frequencies were assumed to represent the excess number of consumer units that had been added by the Brookings authors in the several income brackets above about $\$ 7,000$. (Actually, they represented the excess number of persons, rather than consumer units, with total incomes in these brackets, but the top tail of the Brookings distribution of consumer units was so similar to that for persons-compare Tables 26 and 37 in the Brookings study-that further adjustment was not warranted.) Accordingly, these frequencies were subtracted from the Brookings number of consumer units in those income brackets (ibid., p. 227), and corresponding subtractions were made from the Brookings aggregate income figures. The total number of units subtracted in brackets above $\$ 7,000$ was then added to the Brookings frequencies in the income range between $\$ 5,000$ and $\$ 7,000$, and the aggregate income in that range increased accordingly. The effect of the adjustment was to reduce aggregate income in the Brookings distribution by $\$ 1.8$ billion.

Adjustment of 1929 family income distribution to meet control totals. The Brookings distribution accounted for 36.5 million families and unattached individuals. The control total estimated from revised Census Bureau figures was 36.1 million. The latter figure was distributed in proportion to the adjusted frequencies that had been derived in preceding steps, and multiplied by estimated mean incomes for the various income brackets. The results required only minor adjustment to meet the control total of family personal income derived for 1929 from the OBE personal-income series (see notes to Table 1, columns 1 and 2).

The 1929 distribution that was derived above is presented, after conversion into 1950 prices, in Table 8 . Like the estimates for 1935-1936 and 1941, the figures for 1929 in Tables 7 and 8 are not part of the official series of the OBE which covers selected years from 1944 forward. 
For the latter period the extension into lower-income brackets of the requirement to file federal individual income tax returns yielded more adequate basic information from tax returns covering a much wider income range than was available for prewar years. For 1929, as is noted in the text, the income distribution presented here is to be regarded as a rough approximation to the actual situation. The adjustments described above serve to make the 1929 distribution more nearly comparable to the income distributions for later years than are the Brookings Institution figures on which they are based. However, a detailed reworking of the 1929 estimates to introduce greater comparability with the distributions for later years might result in significant revisions in the figures.

\section{5-1936, 1941}

Selma Goldsmith, George Jaszi, Hyman Kaitz, and Maurice Liebenberg, "Size Distribution of Income since the Mid-Thirties," Review of Economics and Statistics, February 1954, Tables 3 and 4.

$1944,1946,1947$

Percentages in Table 7 from Income Distribution in the United States by Size, 1944-1950, Table 3, p. 81. The 1944 income distribution in terms of 1950 dollars in Table 8 from Goldsmith, Jaszi, Kaitz, and Liebenberg, op. cit., Table 3.

1950,1951

Survey of Current Business, March 1955, Tables 9 and 10, pp. 24-25. 1954

Table 7 from Survey of Current Business, June 1956, Table 5, p. 12. Table 8 was obtained by applying the oBE price index used for deflating personal consumption expenditures to the distribution of current dollar incomes from ibid., Table 16, p. 15. For methodology, see Income Distribution in the United States by Size, 1944-1950, p. 38, f. 12.

\section{O M M E N T}

Joseph A. Pechman, committee for economic DEVELOPMENT

Selma F. Goldsmith has covered a great deal of ground with the thoroughness and skill we have learned to expect from her. Although her paper is directed mainly at a comparison of census income distributions with other data, the last section, "Longer-Run Changes in Income Distribution," provides for the first time complete distributions covering the period from 1929 through 1953 on a comparable basis. 


\section{CHANGES IN RELATIVE DISTRIBUTIONS}

Table 7 of Mrs. Goldsmith's paper, which summarizes the available estimates, shows that the relative distribution of income changed drastically between 1929 and 1944 . The top 20 per cent of the family units received 54 per cent of total family personal income in 1929, and only about 46 per cent in 1944; the share of the top five per cent was cut by almost a third during the same periodfrom 30 per cent in 1929 to about 21 per cent in 1944. This transformation of the income distribution during the 1930's was so marked that Arthur F. Burns described it as "one of the great social revolutions of history." 1

According to Mr's. Goldsmith's data, the transformation in the income distribution was completed by 1944; during the following ten years there was no apparent movement toward either greater or less equality, the share of the top 20 per cent of the family units varying between 45 and 46 per cent, and the remaining shares showing equal stability. The Survey of Consumer Finances indicates that the distribution was practically unchanged in 1954 and 1955 as well.

These data confirm the conclusions drawn by Kuznets from income tax returns, ${ }^{2}$ and the broad sweep of events-so far as they can be portrayed by the available data on income size distributions - seem reasonably certain. However, before taking the figures at face value, we must not overlook Mrs. Goldsmith's reservation that "the amount of change in the relative distribution of income depends in part on the particular income definition used." 3

Use of the family personal income concept consistent with the definitions of the Lepartment of Commerce national income accounts for the relatively long period covered by Mrs. Goldsmith would appear to insure comparability of the data. In fact, however, changes in the tax laws and in tax practices have greatly altered the content of family personal income. Methods of employee compensation have been devised to avoid the high tax rates; special tax-relief provisions have lowered reported business or property incomes; advantage has been taken of the preferential capital gains rates by conversion of ordinary income into capital gains; and the practice of

\footnotetext{
${ }^{1}$ Looking Forward, 31st Annual Report, National Bureau of Economic Research, 1951 , p. 4.

${ }^{2}$ Simon Kuznets, Shares of Upper Income Groups in Income and Savings, National Bureau of Economic Research, 1953.

${ }^{8}$ For an excellent discussion of some of the points presented below, see George Garvy, "Functional and Size Distributions of Income and Their Meaning," Papers and Proceedings of the American Economic Association, May 1954, Pp. 236-253.
} 
splitting incomes among family members other than the wife has grown. Since the Department of Commerce relies heavily on the bookkeeping and tax records of business firms and individuals for making its estimates, the size distributions of "family personal income" are actually based on income definitions which have undergone considerable change in recent years.

\section{EFFECTS OF CHANGES IN TAX LAWS AND TAX PRACTICES}

The precise effect of these changes cannot now be measured, but there is little question about the direction of this effect. Most of the developments noted above, though by no means all, favor the top 1 or 2 per cent of the nation's income recipients. As a consequence, there must be understatement of inequality in the currently available income size distributions for the period since the beginning of World War II if 1929 is used as a basis for comparison. Equally important, the amount of understatement has probably been increasing in recent years as taxpayers become more expert at designing new methods of avoiding the impact of the high tax rates and as Congress continues to enact new relief provisions for the same purpose. This means that the apparent stability in the relative distribution of income since 1944 may conceal a gradual but persistent increase in inequality.

Lest this qualification to Mrs. Goldsmith's conclusions be lightly dismissed, it might be worthwhile to list some important examples of these changes in income accounting. While any one may perhaps have little effect on the distribution of income, their combined effect can hardly be ignored.

Devices for reducing stated earnings have been elaborated during the past fifteen years for the benefit of high-salaried executives and self-employed business and professional men. Deferred-compensation contracts and stock options are arranged in lieu of cash salary increases, and often tax-free expense accounts are used to pay not only legitimate business expenses but also large personal expenditures of the individual and his family. Deferred compensation becomes income to the corporate executive only when he elects to take it rather than when it accrues, while the value of stock options is never included in personal income because it is regarded by the tax laws as a capital gain. As for the so-called business expenses, the Department of Commerce charges them off as nonfactor costs of business operation, and they are therefore not counted as employee compensation or entrepreneurial incomes.

Of these practices, the expense accounts are by far the most important. Individuals have at their disposal company cars, planes, 
boats, and other company facilities for personal and family use; they charge off as entertainment expenses the cost of theaters, night clubs and restaurants, baseball games, boxing matches and other sports events; and they finance expensive travel and pleasure cruises for themselves and their families. ${ }^{4}$ It is impossible to estimate even roughly how much income is distributed to individuals in this form, but clearly the amounts are now much larger than in the 1920's and 1930's, both in absolute and relative terms, and are highly concentrated at the upper end of the income distribution.

The effect of the recent growth in industrial pension plans and other fringe benefits is not reflected in Mrs. Goldsmith's income distributions. Family personal income excludes employer contributions to such plans, ${ }^{5}$ an item of accrued income to individuals which has increased many times more than cash wages and salaries. These contributions were over five times larger in 1954 than in 1944 (\$5.1 billion as compared with $\$ 0.9$ billion), while wage and salary disbursements increased by less than 70 per cent during the same period. ${ }^{6}$ Other nontaxable fringe benefits (such as life insurance and medical care and health insurance) have also been increasing rapidly in recent years. Although such benefits are less concentrated at the upper end of the income scale than deferred compensation or stock options, they do not extend down to the lowest end. For example, farm workers and employees in service, retail, and other small establishments ordinarily have few wage supplements of this kind, whereas the more skilled and unionized workers have succeeded in obtaining substantial benefits through collective-bargaining agreements. If one could distribute employees' rights in pension and other plans by personal income levels, practically all of the $\$ 5$ billion of additional income from this source would be added to the upper end of the income distribution in 1954 (perhaps the top half); only a small fraction of this amount would be added in 1944 and earlier years.

The effects of special tax relief on the taxable incomes of industrial organizations and property owners may be illustrated by the provisions applying to the oil and mining industries. Since the 1920 's the oil industry has been allowed a deduction for depletion amounting to $27 \frac{1}{2}$ per cent of gross income, and it has also been en-

"For an interesting account of these and other methods which are used to escape the impact of high tax rates, see Business Week, July 16, 1955, p. 45.

"Income Distribution in the United States by Size, 1944-1950, supplement to Survey of Current Business, Dept. of Commerce, 1953, Exhibit 11, p. 53.

- National Income Supplement, 1954, Survey of Current Business, Dept. of Commerce, Table 34, p. 210; and Survey of Current Business, July 1955, Tables 3 and 34, pp. 10 and 20 . 
titled to deduct currently most of the cost of oil-well development and drilling. Almost every major federal revenue act in recent years has contained some new feature broadening the application of these allowances to other extractive industries. For example, in 1951 percentage depletion was raised from 5 to 10 per cent for coal, and a long list of minerals was added to those already entitled to percentage depletion. In the same year, taxpayers were allowed to deduct currently mineral exploration expenses up to $\$ 75,000$ per year for a period of four years, in lieu of capitalizing them. In 1954, uranium and several other strategic and critical minerals were granted percentage depletion of 23 per cent, and the $\$ 75,000$ annual limit on the deduction for mineral exploration expenditures was raised to $\$ 100,000$.

The Department of Commerce adds back the excess of percentage depletion over cost depletion to net income of unincorporated enterprises, but it does not correct for the additional deductions for development and exploration. Moreover, Mrs. Goldsmith did not distribute the major portion of the excess depletion allowances to the highest income brackets where it belongs. ${ }^{7}$ It has been estimated that the special allowances for unincorporated owners of oil and mining interests may have reached a total of $\$ 700$ million in $1955 .^{8}$ Thus, the effect of these allowances on the comparability over time of the incomes of the highest income recipients is by no means small, particularly since the oil industry (which accounts for the major share of the special allowances) has been growing at a faster rate than most other industries.

The definition of key items of business cost-aside from depletion and mineral exploration expenditures-has been liberalized in several respects either by law or through changes in the tax regulations. The use of LIFo, five-year amortization allowances for emergency facilities, more liberal depreciation provisions, and the treatment of expenses for research and development and for soil and water conservation as currently deductible expenses have all had the effect of reducing not only corporate profits (which are not included in a distribution of personal income) but also farm and nonfarm proprietorship and partnership incomes (which are

\footnotetext{
7 Apparently excess depletion was distributed by income classes along with other adjustments to the basic tax data on entrepreneurial incomes "in such a manner as to leave the Lorenz curve [based on net incomes as reported on tax returns] in each industry unchanged" (Income Distribution in the United States by Size, 19441950 , p. 44).

${ }^{8}$ William F. Hellmuth, Jr., "Erosion of the Federal Corporation Income Tax Base," Federal Tax Policy for Economic Growth and Stability, Papers Submitted by Panelists Appearing before the Subcommittee on Tax Policy, Joint Committee on the Economic Report, 84 Cong., 1st Sess., 1956, p. 914.
} 
included). Since the Department of Commerce follows the tax definitions of these deductions, family personal income and its distribution understate entrepreneurial incomes in the 1940's and 1950's (or, alternatively, overstate them in earlier years).

Prior to 1948, it was common practice among high-income recipients to split their incomes with their wives in order to avoid the high tax rates. After income splitting was universalized by the Revenue Act of 1948, this practice was no longer necessary (since the tax law in effect granted to each married couple the most advantageous split), but the advantage of splitting with children still remained. A married individual with a taxable income of $\$ 100,000$ and three children would pay $\$ 53,640$ in tax under present law rates, if he retained ownership to all the income. If, on the other hand, the family financial affairs were so arranged (by gift of property, for example) that each child were the recipient of $\$ 20,000$ of the $\$ 100,000$ income (which together with the two $\$ 20,000$ splits he has on his own joint return with his wife, would yield the lowest possible tax), he would reduce the total tax burden on the family to $\$ 36,300$, and thus save $\$ 17,340$ or 32 per cent. $^{9}$

Obviously, it would be difficult for an individual to arrange his affairs so perfectly as to get the maximum advantage from splitting. However he can achieve a major portion of his objective by splitting off only part of his income, since the amounts given to his children would be taxable at the highest rates in his hands. Thus, in the above example, if $\$ 10,000$ were given to each of the three children, the total tax burden of the family would be $\$ 40,740$ and they would be realizing almost 75 per cent of the maximum possible savings. We have no basis for judging how far taxpayers have gone in this direction; but, since the incentive is there, ${ }^{10}$ it can be stated with a fair degree of certainty that such splitting is taking place, and the likelihood is that it is increasing in importance in view of the continuation of the high surtax rates. ${ }^{11}$

Theoretically, a distribution of income by family units should

\footnotetext{
${ }^{\circ}$ The head of the family would be required to pay a gift tax on the property given to his children, but the income tax savings are much larger than the gift tax.

${ }^{10}$ Aside from the income tax incentive, a wealthy individual is well advised to distribute his property to his heirs while he is still living, because the gift tax rates are much lower than the estate tax rates.

${ }^{11}$ The pressure on Congress to validate family partnerships indicates how strong the incentive to split with children really is. An individual would give a gift of property to his child (even if he is a minor) and the child would turn around and "invest" the gift in his parent's business. The parent would then be able to pay part of his entrepreneurial income to the child as a return on the child's investment. This practice had a long and uncertain history in the courts until 1951, when it was made valid for tax purposes.
} 
combine the separate incomes of all members of the family unit. But we do not know whether the field survey data, which must be used for this purpose, ${ }^{12}$ are reliable enough at the higher income levels to provide an adequate basis for making the appropriate combinations.

To convert ordinary incomes into capital gains, taxpayers have used two principal methods: arranging their transactions to result in the receipt of capital gains rather than ordinary income and convincing Congress to define their incomes as capital gains. An example of the first method is the device known as the "collapsible" corporation, frequently used by movie stars before the practice was outlawed in $1950 .{ }^{13}$ More recently, some court decisions have validated a method of converting oil royalties into capital gains. ${ }^{14}$

As to the second method, the list of incomes formerly considered ordinary incomes that are now defined by law as capital gains includes coal royalties, profits from livestock held for twelve months or more, the value of unharvested crops sold with land, profits from subdividing real estate by persons other than real estate dealers, royalties of an inventor, and profits from the sale of timber. Heavy reliance must be placed on data from tax returns to distribute entrepreneurial and property incomes by income level, ${ }^{15}$ and the inclusion of such receipts in individual tax returns as capital gains means that either an inadequate allowance or none is made for the resulting understatement of ordinary incomes.

Finally, the ease with which accumulated corporate savings can be converted into capital gains has important consequences for income distribution analysis. The urge to liquidate these funds in some way other than the dividend route is great, and many tax lawyers spend their time quite profitably devising complex corporate rearrangements to do this very thing. And there are provisions

${ }^{13}$ Income Distribution in the United States by Size, 1944-1950, pp. 56-57.

${ }^{13}$ The device operated as follows: A movie star would organize a corporation to film a movie. He and others would purchase stock in the corporation to provide the cash necessary to make the film. After the film was completed, but before any income was realized, the film would be sold. The corporation would then be liquidated and its assets (mainly cash) distributed to the shareholders. The shareholders would pay a tax, at capital gains rates, on the difference between the cost of their stock and the amount they received on liquidation of the corporation. In this way, the shareholders would convert what would ordinarily have been salaries or dividends into capital gains.

${ }^{14}$ This is accomplished by selling the rights to receive a royalty from an oil property for a short term of years at a price roughly equal to the present value of the future stream of royalties. Since the right is regarded as a capital asset, the gain from the sale of the right may be considered as capital gain.

${ }^{15}$ Income Distribution in the United States by Size, 1944-1950, pp. 41-42 and 52-55. 
in the Internal Revenue Code specifically designed to assist them in these efforts. For example, under the 1954 tax code, a complete redemption by a corporation of a shareholder's stock results in a receipt of a capital gain rather than a dividend if the shareholder does not reacquire an interest in the corporation for a period of ten years thereafter. ${ }^{16}$ In 1950, the heirs of a decedent who owned a closely held corporation were permitted to redeem the stock in that corporation income-tax-free to pay the estate tax, under conditions which can be met fairly frequently. ${ }^{17}$ And there are such esoteric methods as the use of "spin-offs," "split-ups," and "preferred-stock bail-outs," which enable shareholders to cash in on accumulated corporate savings without liability to personal income tax rates on the proceeds. In these and many other instances, stock is redeemed or sold at a value far in excess of its original cost, so that the redemption or sale merely converts corporate savings or potential dividends into capital gains.

Another device which has been used frequently, particularly during the 1950's, is the merger. Although tax reduction is not ordinarily the major motivation, studies by the Harvard Business School have indicated that "the tax structure definitely exerts strong pressure on the owners of many closely-held businesses to sell out or merge with other large companies. . . The tax incentives to sell are twofold: first, a closely-held business may be sold out to lessen the impact of the estate taxes; and, secondly, the sale may enable the owners of closely-held businesses to take the profits out of their business by the capital gains route rather than to have them distributed as dividends and subjected to the very high bracket individual income tax rates. . .."18

The relative ease with which corporate savings can be distributed to shareholders via the capital gains route raises the question of the validity of size distributions of income which exclude corporate savings or unrealized capital gains. As Mrs. Goldsmith has pointed out, the addition of undistributed corporate profits and corporate profits taxes wipes out a substantial portion of the decline in the income share of the top 5 per cent of the income recipients between 1929 and recent years. ${ }^{19}$ She might have added that it could also alter the picture of relative stability that we now have for the years since the end of the war.

${ }^{10}$ Internal Revenue Code of 1954, Sec. 302. The purpose of this provision is explained in the Report of the Committee on Finance, United States Senate, to Accompany H. R. 8300 (Report No. 1622, 83d Cong., 2d sess., p. 45).

${ }^{17}$ Internal Revenue Code of 1954, Sec. 303.

${ }^{18} \mathrm{~J}$. Keith Butters, John Lintner, and William L. Cary, Effects of Taxation, Corporate Mergers, Harvard Business School, 1951, pp. 8-9.

${ }^{20}$ See her paper in this volume, p. 95. 
These remarks are not intended to disparage Mrs. Goldsmith's work in any way. We owe a tremendous debt of gratitude to her and to her colleagues at the Department of Commerce for the enormous body of useful statistics on income size distributions which they have made available to us. That they are aware of the shortcomings of their data is evident from the detailed statement of their methodology in Income Distribution in the United States. At this stage of their work, they are greatly in need of more information to evaluate the real meaning of their results and to place them in their proper historical perspective. Such information can be obtained from a detailed examination of the supporting schedules submitted by taxpayers with their tax returns. Careful consideration should be given to methods of securing and tabulating this information-even if it means the loss of some of the regular annual tabulations that now appear in Statistics of Income.

\section{ROBERT J. LAMPMAN, UNIVERSITY OF WASHINGTON}

The papers presented in Part I demonstrate that serious and continuing attempts to find and understand the facts of size distribution have only begun and that those in authority must make positive decisions, plan carefully, and act energetically if the facts are to be forthcoming. My comments will be on three aspects of the problem.

\section{SCHEDULE CHANGES}

New questions suggested by a reading of the papers include the following possibilities: one relating the reported income to the recipient's labor-force status of the year in which the income was received, rather than to labor-force status at time of interview; one relating family status and composition to the year for which income is reported; and a series of questions designed to get more complete information on totals of family income (which could, at least, test the widely held belief that extra probing will uncover additional income-especially unearned income-and income recipients). In addition, I suggest trying a question in a small sample study on how the income recipients place themselves on the economic status ladder, thus opening a new "subjective frontier" in income sizedistribution research.

\section{CHANGES IN PRESENTATION}

How can the 1959 data be organized for improved presentation? Information about differences among the deciles in money income distribution of families and unattached individuals would eliminate certain misleading features of simpler tables and make for better interpretation. I suggest a table set up to show for each decile: 


\section{CENSUS INCOME DATA}

Median income-receiving-unit income

Percentage of all persons to be found in each decile of incomereceiving units ${ }^{1}$

Median number of children under eighteen

Percentage of units headed by persons over sixty-five

Percentage of units having rural residence

Median number of earners

Percentage of units headed by women

Percentage of units headed by workers who were in the labor force less than six months

This list is meant to be suggestive rather than exhaustive or necessarily the best.

\section{PROBLEMS OF DEFINITION}

It is important that we understand not only the money income distribution and its association with factors such as those noted above, but also how the degree of inequality and changes in it shown in the census money income distributions depend heavily upon the particular definitions of income, income recipient, and income period used. Table 1 offers a beginning toward a reconciliation of all possible size distributions and estimated changes in the degree of inequality shown, starting from the current census definitions of total family money income. Three definitions of income are emphasized: consumer-power income, which is relevant for the welfare judgment; producer-contribution income, which indicates inequality before income redistribution via public and private institutions; and general-market-power income, which is broad enough to cover many shifts in the form that income takes. Some change in the definition of income recipient and income period may be appropriate in working out changes in the definition of income. For example, in drawing up a consumer-power income distribution, it would be reasonable to adjust the income-receiving-unit definition to show the number or percentage of persons in each decile of income-receiving units and to lengthen the time period beyond one year.

Some of the relationships suggested in the table could well be the subject of special sample studies or other methods of inquiry by the Census Bureau and others. But at present, without further inquiry into the facts, some interpretation could be offered of the

${ }^{1}$ I discovered after considerable effort that the top decile of income-receiving units included 12 per cent of the people, the bottom decile 6 per cent in 1949. 
Reconciliation of Income Definitions and Estimate of Effect of Adjustments on the Degree of Inequality Shown in Census Family Income Distributions

ADJUSTMENT TO DISTRIBUTION

Estimated Effect on

Degree of Inequality

Shown

Part A. Changes in Definition of Income

Total money income

Add: Nonmarketed net product

Net imputed rent of owner-occupied houses

Home-produced food

Home-produced services

Services of consumer durables

Withheld dividends or corporate savings

In-kind payments

Employee fringe benefits

Business expense accounts over and above the "cost of work"

Deduct: Money transfers from government to persons

Equals: Producer-contribution income

Add: Money transfers from government to persons

Personal transfers (gifts, gambling gains and losses, etc.)

Deduct: Withheld dividends

Personal taxes paid

Adjust for: Cost-of-living differences (urban-rural)

Equals: Consumer-power income d

Adjust for: Changes in value of assets owned

Equals: General-market-power income

$$
\text { (realized and unrealized capital gains) }
$$

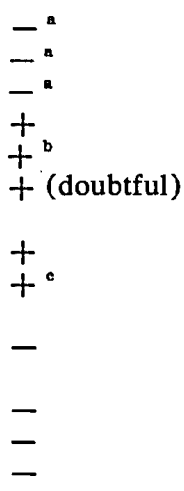

differ by years

Items which are difficult to assign to individuals:

Indirect taxes

Government free services

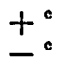

Part B. Changes in Definition of Income-Receiving Unit and Income Period

Convert to distribution by earners (reshuffling)

Adjust above distribution to exclude part-period earners

$+$

Adjust spending-unit distribution to exclude units having part-period principal earners

Convert to a per capita income distribution, ranking individuals by per capita income (reshuffling)

Adjust spending-unit distribution to show percentage of total population represented in each decile of spending units (no reshuffling)

Include institutionalized population

Lengthen income period to more than one year

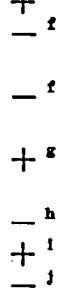

Part C. Suggestions Based on Findings of Inadequacies in Census Data

Adjust for fact that census has:

Greater understatement of self-employment income for farm than nonfarm

For farm families, assignment of product of unpaid family workers to family head distorting individual earner distribution

Differential underreporting of transfer income

Deficiency of income recipients, particularly secondary family recipients, ${ }^{\mathrm{n}}$ recipients of income other than earnings, ${ }^{\circ}$ young adult males, nonwhites ${ }^{\circ}$ and urban females. ${ }^{\circ}$

Too many small families and unattached individuals ${ }^{\mathrm{q}}$

$-2$

no effect on family distribution ${ }^{2}$

$-^{\mathrm{m}}$

$+p$ 


\section{Notes to Table 1}

"Margaret G. Reid, "Distribution of Nonmoney Income" in Volume Thirteen (1951) of Studies in Income and Wealth, pp. 124-178. On the importance of nonmoney income to farm families, see the paper by D. Gale Johnson in this volume, p. 288.

'Simon Kuznets, Shares of Upper Income Groups in Income and Savings, National Bureau of Economic Research, 1953, Table II, p. 36; also see the distribution of the Office of Business Economics.

"John H. Adler, "The Fiscal System, the Distribution of Income, and Public Welfare," Fiscal Policies and the American Economy, Kenyon E. Poole, editor, Prentice-Hall, 1950, pp. 359-421, see especially pp. 384-388.

"Close to OBE "family personal income."

Kuznets, op. cit., p. 103.

"George Garvy, "Some Problems in Measuring Inequality of Income" in Volume Fifteen (1952) of Studies in Income and Wealth, pp. 25-47, 37, 43.

${ }^{B}$ Kuznets, op. cit., pp. 104-107.

${ }^{2}$ For postwar distributions we know there are fewer people per decile below the median than above it.

${ }^{1}$ Most standard distributions exclude the institutionalized population and hence underrepresent the single individuals and low-income units.

${ }^{3}$ Kuznets, op. cit., pp. 139-140. Making adjustments for temporary low income status and size of the spending unit will substantially lessen the number who can be asșigned "low economic status" (see the paper by Eleanor M. Snyder in this volume).

Johnson, op. cit., pp. 294 and 299.

${ }^{1}$ Ibid., p. 288.

m See the paper by Selma F. Goldsmith in this volume, p. 78.

${ }^{n}$ See the paper by Edwin D. Goldfield in this volume, p. 57.

- See the paper by Leon Pritzker and Alfred Sands in this volume, pp. 216 and 231.

${ }^{p}$ Effect on inequality mixed since adding both income and income recipients to low-income classes and some income to higher deciles.

'Goldsmith, op. cit., p. 86 (contradicts above line in part).

conceptual relationships. Also, users of census income data should be alerted to the determinants of inequality which could be classified in Part $\mathrm{C}$ of the table-those arising from errors of questioning, response, and editing.

We now have, of course, the excellent series by the Office of Business Economics estimating something close to the consumerpower income distribution suggested above. It seems to me that there is ample justification for developing two series which would approximate the distribution of producer-contribution income and general-market-power income to place alongside the census total money income and the OBE personal income distributions.

\section{EDWIN MANSFIELD, CARNEGIE INSTITUTE OF TECHNOLOGY}

I have been asked to comment on the census income data for small areas-states, counties, and cities. I shall discuss briefly the nature of these data, some of their uses, and some difficulties that seem to be present in them. 


\section{CENSUS INCOME DATA FOR SMALL AREAS}

The income data published in Volume II of the 1950 census may be classified into two groups. ${ }^{1}$ The first deals with the incomes of families and unrelated individuals. Income distributions and medians are provided for them in every state, county, standard metropolitan area, urbanized area, and urban place with more than 2,500 inhabitants. For states, separate data are presented for families and for unrelated individuals; for other areas (except urban places with less than 10,000 inhabitants), separate data are presented for families alone. The state and county data are broken down for the urban, rural nonfarm, and rural farm populations. ${ }^{2}$

The second group of data deals with the income of persons. Income data are given by race and sex; by age and sex; by family status, age, and sex; by weeks worked and sex; by class of worker and sex; and by type of income and sex. These data are published for each state, for the farm and nonfarm populations in each state, and for each large standard metropolitan area. In addition, income data are published for the experienced civilian labor force in each state by occupation and sex, and by industry and sex. ${ }^{3}$

In southern states, some additional information is given on income among nonwhites. Income distributions and medians are presented for nonwhite families and unrelated individuals in each state, county, standard metropolitan area, urbanized area, and urban place with more than 10,000 inhabitants. Separate state data are published for the rural farm, rural nonfarm, and urban populations.

\section{SOME USES FOR THE DATA}

Economists have long been interested in the personal distribution of income because of its welfare implications and its influence on total consumption and resource allocation. In empirical studies, considerable attention has been devoted to income differentials arising among occupations, industries, geographical areas, and other categories. The purpose of much of this work has been to understand more fully the underlying forces that produce an income distribution and that cause temporal changes in such distributions. Presumably, an ultimate objective is the construction of a

\footnotetext{
I Although much of the census income data for small areas is located in Vol. II, other parts of the census contain relevant information. See for example 1950 Census of Population, Vol. IV, Special Reports, Part 5, Chap. A, Table 4.

${ }^{2}$ The urban and rural nonfarm populations are combined in the county data.

s Data concerning the wage or salary income of the experienced labor force are also provided for states, large standard metropolitan areas, and large urban places.
} 
model able to explain much of the observed variation in income and one that can be tested empirically.

Studies focusing on interarea income differentials have usually relied on the Department of Commerce state per capita income series, on census data, or on the Study of Consumer Purchases. Although the Commerce series has probably been used most often, ${ }^{4}$ the other bodies of data have also been important. ${ }^{5}$ Moreover, the 1950 census has provided material, not previously available, for studies of intercity and intercounty differences in income level and interarea differences in the distribution of income. Some work has been done with these data ${ }^{6}$ but they should afford an important basis for further study.

The 1950 census data may also be useful in cross-section analyses. Because statisticians have become increasingly aware of the problems inherent in most time series and because of the increased interest in breaking down the totals, many studies have relied on cross-section data or a combination of cross-section and time-series data. ${ }^{7}$ Of course, the usefulness of the census data in this context depends on the purpose of the study, on whether the time interval and coverage correspond with other data, and on other factors.

Finally, the census income data for small areas may be useful to workers in various other fields:

To economists interested in regional development, interregional input-output models, and other matters relating to the spatial structure of the economy.

To economists and statisticians engaged in sampling small areas,

'See, for example, papers in Review of Economics and Statistics: Frank A. Hanna, "Contributions of Manufacturing Wages to Regional Differences in Per Capita Income," February 1951; Howard G. Schaller, "Veterans Transfer Payments and State Per Capita Incomes, 1929, 1939, and 1949," November 1953.

${ }^{5}$ See, for example, Herbert E. Klarman, "A Statistical Study of Income Differences among Communities" in Volume Six (1943) of Studies in Income and Wealth; D. Gale Johnson, "Some Effects of Region, Community Size, Color and Occupation on Family and Individual Income," and the comment on it by Herman Miller and Edwin Goldfield in Volume Fifteen (1952) of the same series.

"See, for example, Thomas R. Atkinson, "Money Income Distribution: South vs. Non-South," presented at the 1954 Southern Economic Association meeting; and my papers, "City Size and Income, 1949" in Volume Twenty-one (1957) of Studies in Income and Wealth; and in Review of Economics and Statistics, "Community Size, Region, Labor Force, and Income, 1950," November 1955, and "Some Notes on City Income Levels," November 1956.

${ }^{7}$ For example, two studies where the city is used as a unit are James S. Duesenberry and Helen Kistin, "The Role of Demand in the Economic Structure," in Studies in the Structure of the American Economy, Wassily Leontief, editor, Oxford University Press, 1953; and Dorothy Brady, "Family Savings in Relation to Changes in the Level and Distribution of Income" in Volume Fifteen (1952) of Studies in Income and Wealth. 
especially, of course, where it seems desirable to stratify the sampling units by income level.

To businessmen interested in marketing studies, as exemplified by the results of a survey (intended to determine the usefulness of census data in marketing) published by the American Marketing Association. Eighty-eight per cent of the respondent firms used census data, and their purposes suggest the value to them of the income estimates for small areas. ${ }^{8}$

To government workers needing information related to economic welfare, to geographical inequality in tax bases and fiscal capacity, and to planning.

To sociologists, city planners, housing experts, and demographers. The data have been used in studies of urban and metropolitan structure and of family income distribution in deficient housing areas. ${ }^{9}$

\section{SOME DIFFICULTIES PRESENT IN THE DATA}

Many of the difficulties confronting an individual user of these data arise because they are collected not for use in a particular model or conceptual framework but for a multitude of uses. Like most general-purpose items, they are sometimes only an approximation to what would be most useful for particular purposes. Others may have become aware of a different set of difficulties. Some of those I have encountered are discussed below.

\section{Combination of Data on Families}

\section{and Unrelated Individuals}

For cities of under 10,000 inhabitants, the 1950 census provides the median income of families and unrelated individuals combined, but it does not provide separate medians for each group. This creates difficulties for persons who must include small cities in their studies. ${ }^{10}$

It is well known that the characteristics of the two groups differ. In particular, the income level among families is substantially higher than that among unrelated individuals, ${ }^{11}$ and hence the median in-

${ }^{8}$ N. H. Borden, S. Frame, W. C. Gordon, and C. W. Smith, "An Appraisal of Census Programs for Marketing Uses," Journal of Marketing, April 1954.

${ }^{\circ}$ See, for example, Leo Schnore and David Varley, "Some Concomitants of Metropolitan Size," American Sociological Review, August 1955; and Morton Hoffman, "Needed Improvements in the Census for Housing Users," Land Economics, November 1955, p. 328.

${ }^{10}$ Apparently, the lack of separate income data for families and unrelated individuals also troubles users of the census tract data (Hoffman, op. cit.).

${ }^{11}$ Selma Goldsmith, George Jaszi, Hyman Kaitz, and Maurice Liebenberg, "Size Distribution of Income since the Mid-Thirties," Review of Economics and Statistics, February 1954, p. 12. 
come of both groups combined may be affected by the proportion of each in a given city. One might suppose that the number of families per unrelated individual is relatively constant from one city to the next and hence that this factor is relatively minor. Instead there appears to be a direct relationship between the number of families per unrelated individual and the median income of families and unrelated individuals. ${ }^{12}$ And the variation in the former is often substantial.

Consequently census data for small cities would probably be more useful if distributions and medians were published for families as well as for families and unrelated individuals. ${ }^{13}$ This would make possible either separate treatment of the two groups or the use of a combined median based on constant weights for them. ${ }^{14}$ Of course, the estimates for families alone would be less precise than the estimates for both groups combined, ${ }^{15}$ but it would be useful to have both sets of data.

\section{Limited Use of Urbanized-Area Concept}

In many types of economic, business, and sociological research, the urbanized area or standard metropolitan area (a thickly settled, highly integrated urban area) is a more appropriate unit of study than the urban place which includes only the legal limits of a city. ${ }^{16}$ It is unfortunate that the urbanized-area concept has been confined to areas surrounding a large central city. Many clusters of smaller urban places may be highly integrated and might be considered urbanized areas. As matters now stand, one must use individual

${ }^{10}$ Among cities of comparable size located in the same region, the number of families per unrelated individual is often higher in those with high incomes than in those with low incomes. There is also a tendency for the number of families per unrelated individual to be higher in standard metropolitan areas than in urban places outside these areas. But there seems to be no tendency for the ratio to be higher among cities of comparable size in high- than in low-income regions. (See my two papers in Review of Economics and Statistics, footnote 6.)

${ }^{13}$ If the distributions for families and for families and unrelated individuals were published, it would be possible to derive the distribution for unrelated individuals.

${ }^{14}$ If a large number of cities were included, weighting and combining of the distributions might consume more time than it would be worth. Rougher methods could be used.

${ }_{15}$ All other things being equal, the standard error of the median family incomes will exceed that of the median incomes of families and unrelated individuals because the sample size is smaller in the former case. If the sample is fairly large, the distribution of the median is approximately normal, and its standard deviation is approximately $[2 \vee n p(\mathrm{E})]^{-1}$ where $p(\mathrm{E})$ is the probability density at the population median and $n$ is sample size.

${ }^{18}$ For definitions of urban place, urbanized area, and standard metropolitan area, see 1950 Census of Population, Vol. II, Characteristics of the Population, Part 1. 
median incomes for many urban places that may be parts of larger urban developments rather than independent entities. This is particularly troublesome if city size is used as a variable or a basis for stratification. ${ }^{17}$

Urban places outside standard metropolitan areas located within five miles of some other urban place or standard metropolitan area in the same state (according to 1950 state maps) are shown below (by census division) as a percentage of all urban places located outside standard metropolitan areas.

$\begin{array}{lrll}\text { United States } & 31 & \text { South Atlantic } & 37 \\ \text { New England } & 66 & \text { East South Central } & 23 \\ \text { Middle Atlantic } & 60 & \text { West South Central } & 14 \\ \text { East North Central } & 30 & \text { Mountain } & 27 \\ \text { West North Central } & 7 & \text { Pacific } & 45\end{array}$

Proximity to other cities is of course an extremely rough indicator of the degree of integration with neighboring cities: But this crude indicator suggests that many urban places outside standard metropolitan areas may be candidates for inclusion in urbanized areas.

\section{Inclusion of Income of College Students}

Incomes of college students are included in the income distributions provided by the 1950 census; hence the median incomes in cities that contain universities are often quite low. For example, the median incomes in Amherst (Massachusetts), Williamsburg (Virginia), and Ithaca (New York) are $\$ 775, \$ 645$, and $\$ 1,150$, respectively. For many purposes, intercity income comparisons are clouded by this factor: the median income in city A may be lower than that in city B merely because the former is the site of some college, and there is no way to determine the weight of this factor or the median income of nonstudent residents. That the effect of student incomes on income levels is fairly widespread is indicated by the following tabulation showing the number of "university cities" (those where college enrollment in 1950 exceeded 10 per cent of families and unrelated individuals) as a percentage of all cities, by region and for particular city-size classes. The city-size classes are: urban places outside standard metropolitan areas (1) 5,0009,999, and (2) 25,000-49,999; standard metropolitan areas (3) 100,000-249,999.

\footnotetext{
${ }^{17}$ The Intensive Review Committee for' the Appraisal of Census Programs has recommended the extension of the urbanized-area concept to the peripheries of smaller cities (see also Thomas Semon, "The Case for a Broader 'Urbanized Area' Concept," Journal of Marketing, October 1954).
} 


$\begin{array}{lccr} & (1) & (2) & (3) \\ \text { United States } & 16 & 28 & 19 \\ \text { Northeast } & 12 & 19 & 0 \\ \text { North Central } & 16 & 29 & 17 \\ \text { South } & 18 & 30 & 29 \\ \text { Far West } & 15 & 27 & 33\end{array}$

Although many problems might arise, ${ }^{18}$ it would be helpful if data were published from which one could derive income distributions that exclude full-time students.

\section{Combined Data on Families and Unrelated Individuals, by Color}

The 1950 census provides income distributions for southern nonwhite families and unrelated individuals combined by state, county, and city. But because separate distributions for families or for unrelated individuals are not published, it is impossible to derive separate distributions for white families and white unrelated individuals. Thus, if one is interested in the income level among whites or nonwhites, one must use the median income of families and unrelated individuals combined. The difficulties that surround this figure are outlined above. ${ }^{19}$ For some types of research, it may also be unfortunate that no income data for nonwhites are published for cities with less than 10,000 inhabitants.

\section{Other Difficulties}

Other difficulties-errors and omissions common to all census income data-may often be important in small-area data. For example, data for some areas are collected by only a few enumerators, and it is not so likely that enumerator biases will cancel out. Also the variation in the level of nonmonetary income is probably greater among small areas than among larger ones. These difficulties are present, and every user of the data should be aware of them even though no quick and easy solution is apparent.

${ }^{18}$ For example, difficulties might arise in determining who should be excluded. There seems to be no reason to exclude most students who live at home and who are counted merely as family members. On the other hand, most full-time students who live away from home and who are counted as unrelated individuals should probably be excluded.

${ }^{10}$ Of course, separate estimates of median nonwhite family income would probably be less precise than the estimates of median nonwhite family and unrelated individual income because the sample size would be smaller in the former case. But this might be a relatively minor matter. 